\title{
IS ACTUARIALLY FAIR INSURANCE PRICING ACTUALLY FAIR?: A CASE STUDY IN INSURING BATTERED WOMEN
}

\author{
Deborah S. Hellman*
}

It is important to note that statutes regulating the business of insurance are not meant to prevent all discrimination, but only unfair discrimination. ${ }^{1}$

\section{Introduction}

In 1995 , the public, ${ }^{2}$ the bar, ${ }^{3}$ and the legislators of several states ${ }^{4}$ began to respond to a 1988 survey of insurers that indicated that internal policy guidelines of approximately half of the nation's largest insurers instruct that health, life and disability coverage be denied to domestic

* Assistant Professor, University of Maryland Law School. I want to thank Scott Brewer, Mark Hager, Sam Kirstein, David Luban, Kate Nicholson, and Alan Wertheimer for their comments and suggestions on earlier drafts. Mary Keyes and Jennifer Rohr provided excellent research assistance.

1 Joyce Nixson Hoffman \& Elizabeth Zieser Kincaid, AIDS: The Challenge to Life and Health Insurers' Freedom of Contract, 35 DRAKE L. REv. 709, 767 (1987). Hoffman is the Associate Counsel and Kincaid the Assistant Counsel of Principal Mutual Life Insurance Company.

${ }_{2}$ See, e.g., Jessica Hall, State Probing Insurance Bias Against Domestic Abuse Victims, DAILY RECORD (Baltimore), June 8, 1995, at A1; Ronald Powers, Insurance Denied to Battered Women, TIMES-PICAYUNE (New Orleans), May 13, 1994, at A2; Steven Thomma, Some Battered Women Denied Health Coverage: Congress Probes Company Policies, Seattle Times, May 13, 1994, at A5; Katherine Q. Seelye, Battered Women Put Insurers on Spot, Pitrsburgh Post-Gazette, May 12, 1994, at A7; Fern Shen, For Battered Spouse, Insurers' Bias Worsens Pain, WASH. Post, Mar. 9, 1995, at A1.

${ }^{3}$ The American Bar Association has been active in its support of both federal and state bills. See Debbie Cenziper, Insurers, Violence Addressed; Bill Aids Coverage to Battered Women, Sun-Sentinel (Fort Lauderdale), Apr. 5, 1995, at 16A. In particular, Lynne Gold-Bikin, chairperson of the Family Law Section of the ABA, has vocally opposed the practice of denying battered women insurance and supported the proposed legislation, particularly the federal bills. See Nightline (ABC television broadcast, Apr. 3, 1995) (transcript no. 3616) [hereinafter Nightline]. Gold-Bikin, speaking on behalf of the ABA, stated: "My position is that they [sic] [the insurance industry] should not be denying benefits to victims of domestic violence by virtue of their status as victims, and they are doing it, and that by doing it, it's an additional act of violence against these women who are trying to get out of the violence cycle." CNN (CNN television broadcast, Mar. 20, 1995).

In addition to the advocacy of Gold-Biken, the ABA's policy-setting House of Delegates encouraged individual states to pass legislation barring insurance companies from refusing to insure domestic violence victims. See Scott Martelle, Law Would Let Victims of Abuse Keep Insurance, Detrort News, Mar. 11, 1995, at C1. ABA President Roberta Cooper stated: "We don't hold victims of a crime responsible for their injuries. Insurance companies do not deny coverage for an individual who has been shot or stabbed by a stranger. They should not revoke coverage when the attacker is a spouse." Id.

${ }^{4}$ See infra Part III. 
abuse victims. ${ }^{5}$ The response: public outcry and legislative and industry action. Some of these insurers voluntarily modified their policies in an effort to stave off regulation. ${ }^{6}$ Nonetheless, laws have been enacted in sixteen states that limit the ability of insurers to use abuse victim status in underwriting and rating decisions-ten of these sixteen since February of $1996 .^{7}$ Similar bills have been introduced in twelve other states ${ }^{8}$ and in both houses of Congress. ${ }^{9}$ While some industry representatives have adopted the viewpoint of their critics, others continue to defend this policy as a principled and fair response to the actuarially documented fact that victims of domestic abuse are more likely to be victimized in the future than are others with otherwise similar risk profiles, thus drawing

\footnotetext{
${ }^{5}$ See Health Insurance and Domestic Violence: Hearings on S. 524 Before the Senate Comm. on Labor and Human Resources, 104th Cong. (1995) [hereinafter Health Insurance: Hearings] (statement of Representative Constance A. Morella) (citing a survey conducted by Representative Schumer in which eight of the nation's 16 largest insurers were found to use domestic violence as an underwriting criterion); see also Judith Gaines, Battered Women Finding Fewer Insurers, Boston Globe, Mar. 12, 1995, Metro/Region, at 1 (listing nine major insurers that "deny or have canceled coverage to battered women": Nationwide, Allstate, State Farm, Aetna, Metropolitan Life, The Equitable Companies, First Colony Life, The Prudential, and the Principal Financial Group).

${ }^{6}$ See Lisa Holton, Insurance Firm Moves to Cover Battered Spouses, CHI. Sun-Times, May 26, 1995, Financial, at 47 (describing State Farm Insurance's change in policy and their formation of the Corporate Alliance to End Partner Violence); see also Health Insurance: Hearings, supra note 5 (statement of Deborah Senn, Washington State Insurance Commissioner) (describing the National Association of Insurance Commissioners' 1995 drafting of a model act, prohibiting the use of abuse status in underwriting, for states to adopt as part of their insurance code's "Unfair Trade Practices Act" statutes).

7 See ArIZ. Rev. Stat. ANN. § 20-448 (West 1996); Fla. StaT. ch. 626.9541 (1995); S.B. 306, 109th Leg., 2d Sess. (Ind. 1996); S.B. 444, 76th Leg., 1st Sess. (Kan. 1996); H.B. 39, 1996 Leg., Regular Sess. (Md. 1996); S.B. 1815, 79th Leg. Sess., 2d Sess. (Minn. 1996); H.B. 1211, 1996 Leg., Regular Sess. (N.H. 1996); A.B. 2769, 219th Leg., 2d Sess. (N.Y. 1996); H.B. 2925, 99th Leg., 2d Sess. (Tenn. 1996); A.B. 1973, 1995 Leg., Regular Sess. (Cal. 1995); H.B. 6935, 1995 Leg., 1st Sess. (Conn. 1995); S.B. 128, 138th Leg., 1st Sess. (Del. 1995); H.B. 247, 76th Leg., 1st Sess. (Iowa 1995); H.B. 1215, 117th Leg., 2d Sess. (Me. 1995); H.B. 4926, 179th Leg., 1st Sess. (Mass. 1995); H.B. 1100, 180th Leg., 1st Sess. (Pa. 1995).

${ }^{8}$ See S.B. 197, 19th Leg., 2d Sess. (Alaska 1996); S.B. 679, 143d Leg., Regular Sess. (Ga. 1996); S.B. 1425, 89th Leg., Regular Sess. (IIl. 1996); H.B. 5532, 88th Leg., 1st Sess. (Mich. 1996); H.B. 5533, 88th Leg., 1st Sess. (Mich. 1996); H.B. 5534, 88th Leg., 1st Sess. (Mich. 1996); S.B. 1191, 207th Leg., 1st Sess. (N.J. 1996); H.J.M. 25, 42d Leg., 2d Sess. (N.M. 1996); H.B. 331, 52d Leg., Regular Sess. (Utah 1996); H.B. 4316, 1996 Leg., Regular Sess. (W.Va. 1996); S.B. 1369, 1995 Leg., Regular Sess. (La. 1995) (defeated); S.B. 138, 92d Leg., 1st Sess. (Wis. 1995); S.B. 5436, 54th Leg., 1st Sess. (Wash. 1995).

${ }^{9}$ Ten bills dealing exclusively with insurance availability for domestic violence victims have been introduced. See S. 467, 105th Cong. (1997) (modifying S. 1630, 104th Cong. (1996)); H.R. 1117, 105th Cong. (1997)) (identical to H.R. 2654, 104th Cong. (1995)); H.R. 3590, 104th Cong. (1996); S. 1630, 104th Cong. (1996); H.R. 3145, 104th Cong. (1996); H.R. 2654, 104th Cong. (1995); H.R. 1920, 104th Cong. (1995); H.R. 1201, 104th Cong. (1995); S. 524, 104th Cong. (1995); H.R. 1191, 104th Cong. (1995). In addition, two identical bills concerning women's health, but including subtitles on insuring domestic abuse victims, were introduced in 1996. See S. 1799, 104th Cong. (1996); H.R. 3178, 104th Cong. (1996).
} 
disproportionately on health, life and disability insurance pools. ${ }^{10}$ Meanwhile, critics of the practice decry what they see as a double victimization $^{11}$-first at the hands of the batterer, then at the pen of the insurer.

This Article examines the claims of both the industry and its critics. In order to determine whether the proposed legislation is necessary to prevent unfair treatment of abuse victims by insurers, we need to ascertain whether the practice it forbids is fair. Insurers maintain that use of the "abuse victim" classification is no different from use of other classifications employed in insurance pricing. On that basis, insurers claim that use of this classification is both consistent with current practice and fair. Insurers routinely charge more for health insurance coverage, or even deny coverage, to potential insureds with poor medical histories ${ }^{12}$ and to potential insureds who work in jobs that are more hazardous than average. ${ }^{13}$ Even where a potential insured's medical history does not warrant denial of coverage, that coverage is often limited by a policy that either denies coverage for a particular medical condition (an exclusionary waiver) or denies coverage for any unnamed condition present at the date of purchase (a preexisting condition clause). While these last two practices have recently come under attack in the political arena, ${ }^{14}$ the focus of such attacks has been the effect on job mobility rather than fundamental fairness. ${ }^{15}$

${ }^{10}$ See, e.g., Shen, supra note 2 (quoting David McMahon, vice president of First Colony Life Insurance, as saying, "Whether it's battering or breast cancer or HIV or a sky diver or a person recovering from breast cancer, if we fail to take these things into account, it could lead us into bankruptcy."); see also Morning Edition: New Law to Make Insurance Companies Cover Abused Women (NPR radio broadcast, Mar. 8, 1995) (describing Prudential's decision to continue denial of coverage to abuse victims as based on the fact that they are "not a good risk").

${ }^{11}$ Lynn Gillin, a community educator with the Metropolitan Battered Women's Program in New Orleans, explains:

This is just another example of how women domestic violence victims continue to be punished rather than their perpetrators. The medical records that a woman can use in court to gain freedom from her abuser can be used to deny her health and life insurance. This victimization is insidious and vicious.

Battered Women Hurt By Policy, Times-PiCayune (New Orleans), Mar. 31, 1995, at B6; see also Nightline, supra note 3 (comments of Lynne Gold-Bikin).

${ }^{12}$ See Donald W. Light, The Practice and Ethics of Risk-Related Health Insurance (Caring for the Uninsured and Underinsured), 267 JAMA 2503, 2504 (1992) (describing the various preexisting conditions for which insurance is routinely denied or for which premiums are raised).

${ }^{13} \mathrm{See}$ id. at 2504 (describing industries that have been found ineligible for health insurance under selected insurer plans).

${ }^{14}$ For example, the Health Insurance Portability and Accountability Act of 1996, Pub. L. 104-191, 110 Stat. 1936 (1996) (codified in scattered sections of 18 U.S.C., 26 U.S.C., 29 U.S.C., and 42 U.S.C.), also known as the Kennedy-Kassebaum bill, prohibits discriminatory practices in the case of insureds who already have health insurance.

${ }^{15}$ See, e.g., Editorial, What the Health-Care Bill Didn't Do, Clinton and Congress 
Insurers justify these underwriting and pricing practices on the basis of a principle known as "actuarial fairness." A pricing scheme is "actuarially fair" if each insured pays a price for coverage that is equivalent to the risk she poses of drawing from the insurance pool, given available information. ${ }^{16}$ Those in poor health pay more for health insurance because they are more likely to draw from the pool created by premium payments than those in average health. Using this method of pricing, the private insurance industry is unable to offer an economically viable insurance product to those in the worst health, termed "uninsurables" by the industry, because their likelihood of drawing large sums from the pool is so great that the price that would have to be charged for "actuarially fair" coverage is not affordable to those needing such coverage.

Part I of this Article examines the question whether the use of the classification "abuse victim" by insurers in pricing insurance is similar to the use of other classifications such as "person with high blood pressure," which the legislation would not prohibit. It looks at arguments for and against the use of the abuse victim classification that are analytically independent of the justifiability of the underlying practice of risk rating. For example, I examine the claim that when a person is accountable for the condition that makes her a poor health insurance risk (the recreational bungee jumper, for example), she may justifiably be charged an actuarially fair rate.

Although the above argument would not justify the use of risk rating in most cases of illness or disability, it may justify risk rating the abuse victim. If the abuse victim, like the bungee jumper, is accountable for the fact that she faces a higher than average risk of injury, then risk rating on the basis of abuse status may be justified. The key word here is "like." Part I of this Article examines the strength of this analogy. In order to do so, it is necessary to unpack the claim that it is fair to charge insureds more for those conditions for which they are accountable. By understanding if, when, and in what circumstances one may justifiably be charged more for actions one takes that affect one's health, we are able to see if this defense of the abuse victim classification is successful.

Alternatively, one can argue that when an insured is at great risk because she is a victim or likely future victim of a crime, it is not fair for her insurance rates to reflect this risk. This argument, like the argument from accountability, examines the similarity between the abuse vic-

Haven't Eliminated the Problem, Bufr. News, Aug. 29, 1996, at B2; Judith Havemann, President Signs Insurance Portability Bill into Law, WASH. Post, Aug. 22, 1996, at A9; Peter Grier, Portable Insurance for Mobile Society, Christian Sci. Monitor, Aug. 21, 1996, at 1 (all noting that the Kennedy-Kassebaum bill makes health insurance portable when an employee changes jobs, but does nothing to help the sick or high-risk individual currently unable to get health insurance).

${ }^{16}$ See, e.g., Kenneth S. Abraham, Distributing Risk 84 (1986). 
tim classification and classifications based on health status, such as high blood pressure, used by insurers in risk rating. If the abuse victim classification is different from these others, the legislation can be supported or rejected without examining the justifiability of risk rating itself. However, Part I begins the larger project by teasing out some basic principles-the role of accountability for health, the importance of community responsibility for risk - that play important roles in determining when risk rating generally is ethically permissible. After looking at these arguments, I conclude that the differences between the abuse victim classification and others used by insurers provide a justification for the proposed legislation.

Interestingly, supporters of the legislation go to great lengths to defend it as necessary to provide abuse victims with equal treatment rather than as necessary because of differences between the use of that classification and others. Insurers are depicted as singling out abuse victims as if that in itself were unfair. But the practices of underwriting and risk rating operate by singling out traits of persons or classes of persons with selected traits and adjusting rates and coverage accordingly. Any defense of the legislation must provide a reason why the abuse victim in particular ought not to be singled out by insurers.

One can also offer a more far-reaching argument for the proposed legislation. The discussion in Part I assumes the justifiability of risk rating. It asks whether differences between the abuse victim classification and other insurance classifications make its use more or less justifiable than use of these others. But perhaps the strong outcry against this insurance practice taps a deeper intuition about the fairness of health insurance underwriting itself. If so, the case of the abuse victim-which has a shock-the-conscience quality-helps us to see what is troubling about risk rating in health insurance more generally. The proposed legislation should thus be supported as an important first step toward a fairer system of health insurance pricing.

Part II of the Article looks at this system of risk-rated health insurance pricing. Its goal is modest. Rather than provide an attack on or defense of the current actuarially based rating methods, Part II aims to uncover the moral commitments that ground prevailing views about health insurance pricing.

Part III looks at the proposed federal and state legislation in light of the arguments advanced in Part I. The Article concludes by endorsing the stronger of the enacted and proposed laws as necessary for the fair treatment of abuse victims and as an important first step toward treating the misfortunes of poor health and disability as communal responsibilities. 


\section{Battered Women and Health Insurance}

This Part examines arguments for and against the claim that it is unfair for insurance companies routinely to deny health insurance coverage to battered women. ${ }^{17}$ These arguments start with the assumption that risk rating in health insurance is itself justified when applied to characteristics of persons such as high blood pressure, chronic arthritis, or smoking which make someone a poor health insurance risk. The purpose is to address the issue narrowly. If the justifiability of the abuse victim classification can be resolved without determining whether actuarially based risk rating is defensible, so much the better. Because it will be difficult to agree about the deeper issue (as it implicates fundamental moral and political differences), if agreement is to be reached, it will most likely come at this level.

Each of the four arguments in this Part looks at a feature of the abuse victim classification which distinguishes it from some other risk classifications employed by insurers. The task is to determine whether the difference picked out by each argument is morally relevant. First, we look at the claim that the abuse victim who stays in an abusive relationship is justifiably charged more for insurance, or denied coverage, because she chooses to remain in the dangerous environment. Second, we look at the

${ }^{17}$ All but two of the bills or laws recently proposed or enacted prohibit the use of the abuse victim classification in health insurance. The Arizona law and the Utah bill do not cover health insurance. See ARIz. Rev. Stat. ANN. § 20-448 (West 1996) (life and disability); H.B. 331, 52d Leg., 1996 Gen. Sess. (Utah 1996) (life and disability). Some of the legislation applies to life, disability, and other forms of insurance as well. See FLA. STAT. ch. 626.9541 (1995) (health and life); S.B. 197, 19th Leg., 2d Sess. (Alaska 1996) (life, health and disability); S.B. 1425, 89th Leg., Regular Sess. (Ill. 1996) (life, health and disability); S.B. 306, 109th Leg., 2d Sess. (Ind. 1996) (accident, sickness, life and disability); S.B. 444, 76th Leg., 1st Sess. (Kan. 1996) (accident, health and life); H.P. 1215, 117th Leg., 2d Sess. (Me. 1996) (life, health and disability); H.B. 39, 1996 Leg., Regular Sess. (Md. 1996) (life and health); H.B. 5532, 88th Leg., 1st Sess. (Mich. 1996) (life and medical disability); H.B. 5534, 88th Leg., 1st Sess. (Mich. 1996) (health); S.B. 1815, 79th Leg. Sess., 2d Sess. (Minn. 1996) (life and health); H.B. 1211, 1996 Leg., Regular Sess. (N.H. 1996) (all types); S.B. 1191, 207th Leg., 1st Sess. (N.J. 1996) (health); A.B. 2769, 219th Leg., 2d Sess. (N.Y. 1996) (all types); H.B. 2925, 99th Leg., 2d Sess. (Tenn. 1996) (health); S.B. , 52d Leg., Regular Sess. (Utah 1996) (life and disability); H.B. 4316, 1996 Leg., Regular Sess. (W. Va. 1996) (life and health); A.B. 1973, 1995 Leg., Regular Sess. (Cal. 1995) (health and disability); H.B. 6935, 1995 Leg., 1st Sess. (Conn. 1995) (all insurers); S.B. 128, 138th Leg., 1st Sess. (Del. 1995) (health and life); H.F. 247, 76th Leg., 1st Sess., (Iowa 1995) (all types of insurance); S.B. 1369, 1995 Leg., Regular Sess. (La. 1995) (all types of insurance); H.B. 4926, 179th Leg., 1st Sess. (Mass. 1995) (property, accident or sickness and life or endowment and health); H.B. 1100,180 th Leg., 1st Sess. (Pa. 1995) (all types); S.B. 5436, 54th Leg., 1st Sess. (Wash. 1995) (all types); S.B. 138, 92d Leg., 1st Sess. (Wis. 1995) (all types). This Article focuses on the proposed prohibition in the context of health insurance only for the sake of both clarity and simplicity. However, because the arguments offered do not rest on a claim that health is special, these arguments will be readily transferable into other insurance contexts. 
claim that use of the abuse victim classification is not actuarially sound. Third, we examine the claim that the abuse victim classification is inappropriate because it holds one person responsible for the actions of another. And lastly, we explore whether the battered woman classification ought to be prohibited because the battered woman is the victim of a crime.

\section{A. The Individual Is Accountable for Her Status}

Insurers and their defenders claim that because the battered woman is responsible for the increased risk of injury she faces, she justifiably may be denied health insurance coverage. The analogy repeatedly seen in the media is one offered by an official at State Farm Insurance: insuring a battered woman is like insuring a diabetic who refuses to take insulin. ${ }^{18}$ In this Section, we will use the State Farm analogy to explore this argument. It is important to note at the outset one important limitation of the analogy. It is only the battered woman who stays with her batterer who can be compared with the diabetic who does not take the medically prescribed insulin. The battered woman who leaves is more analogous to the diabetic who faithfully takes all recommended treatment. ${ }^{19}$ However, the classification policy employed by most insurers does not distinguish between these two cases. ${ }^{20}$ Abuse victims who stay and those who leave are both denied coverage under the policies currently applied by most insurers. At most, this analogy can be used to justify some of the denials of coverage.

\footnotetext{
${ }^{18}$ See Morning Edition: New Law to Make Insurance Companies Cover Abused Women, supra note 10.

${ }^{19}$ At worst, the battered woman who has left her batterer could be compared to the diabetic who once was an unreliable insulin taker and still suffers health consequences from this derelict period. Because it is hard to leave a partner and difficult to know whether one's violent partner will continue to be so, it seems unduly harsh to deny coverage to the domestic abuse victim who has left on the grounds that she could have used more foresight in entering the relationship and could have left it earlier. The insurer treats the two cases the same (abuse victims who stay and those who leave), most likely due both to the fact that women who leave violent partners are often attacked after they leave and to the common phenomenon of abuse victims going through cycles of leaving and returning before the final leave taking (if there is one) occurs. Cf. Nightline, supra note 3.

${ }^{20}$ Most battered women who are denied insurance are denied only after they leave the abusive relationship and attempt to obtain insurance on their own. Lynne Gold-Bikin, chairperson of the ABA Family Law Section, explained: "When you're still married, you are not applying for individual insurance. Usually, you come under your spouse's policy. It's only when you leave that situation and you go out on your own, where you're no longer in the battering situation, that you get caught by the insurance company, who batters you again." Nightline, supra note 3. But see Monica C. Fountain, Insurance Companies Hit Battered Women Too, CHI. TRIB., June 4, 1995, Womanews, at 1 (describing how at least one company distinguishes between present and past victims of domestic violence in insurance applications because the company found no evidence of an increased risk of injury for battered women who had left their batterers).
} 
The argument implicit in the analogy is the following. Whatever you think about the justifiability of denying coverage to the arthritis sufferer who can do nothing to improve his health, surely you agree that the diabetic who refuses to take insulin may justifiably be charged higher rates or denied coverage for any ill health effects of this refusal.

If so, then you also ought to agree that the battered woman who stays with her batterer can be denied coverage or charged substandard rates ${ }^{21}$ for the same reason. This argument raises two questions. First, we need to ask whether the diabetic is justifiably denied coverage for any worsening in her health status that results from this refusal. We need to decide if the insulin example is itself persuasive and if so, on what basis. Second, we need to determine whether the battered woman who stays with her batterer is similar to the insulin refuser. In the following Section, I argue that while the insulin refuser is legitimately denied health insurance, the battered woman is not. The relevant difference between the cases lies in the fact that taking daily shots of insulin is not a great burden, but leaving a spouse or partner is.

In order to see the intuition behind the State Farm example, it will be helpful to consider an easier case first. Suppose an insurer employing risk rating charges different rates to each of two insureds, both of whom are in good health, based on the fact that one goes rock climbing in her spare time while the other goes on long walks. If rock climbers suffer more injuries as a result of this activity than the average insured incurs, it seems fair for rock climbers and only rock climbers to pay for the costs associated with this activity. This conviction seems especially strong if we imagine that the walker likes rock climbing a lot, but does not rock climb precisely because of the danger involved. If the walker is giving up this pleasure in order to safeguard his health, it seems particularly unfair for him to be required to pay part of the costs of rock climbing injuries as the price of access to health insurance.

\section{Accountability and Voluntariness}

But is the insulin refuser like the rock climber, and is the abuse victim who stays with her batterer like the insulin refuser? Much of the discussion of battered women in the legal literature has focused on whether a battered woman acts voluntarily in deciding to stay with her batterer. ${ }^{22}$ This issue has come to light predominantly in the context of battered

21 "Substandard" rates are higher than "standard" rates; "substandard" refers to the insured's health status, not to the rate. See 1 BERTRAM HARNETT \& IRving I. Lesnick, The LaW OF Life aND Health INSURANCE § 3.01[3], at 3-12 (1991).

${ }^{22}$ See, e.g., Donald G. Dutton, The Domestic Assault of Women: PsychologiCal and Criminal justice Perspectives 161-88 (1995); Richard J. Gelles, Abused Wives: Why Do They Stay?, in Abuse of Women: Legislation, Reporting ANd Preven- 
women accused of murdering their batterers, often while the batterer is sleeping or otherwise not posing an immediate threat to the batteree's safety. ${ }^{23}$ Testimony regarding "battered woman's syndrome" has been introduced in courts with increasing frequency in such cases to show that continual abuse can render the woman unable to perceive leaving as a viable option. ${ }^{24}$ The central idea is that the cumulative, traumatic, and damaging effect of spousal abuse renders the woman's actions less than fully voluntary. ${ }^{25}$

Some feminist scholars have criticized the battered woman defense for depicting women as suffering from a syndrome and as lacking strength of will. ${ }^{26}$ These writers reject the focus on whether the battered woman acts voluntarily because they view that focus as bad for women. ${ }^{27}$ This Article also focuses our attention elsewhere, but for different reasons. What counts as voluntary action is a difficult question from both the psychological and philosophical points of view. If I can proceed without unraveling it, all the better. In the three cases I discuss (the rock climber, the insulin refuser, and the battered woman who stays), the relevant inquiry is whether each actor is accountable ${ }^{28}$ for the decision involved.

Voluntariness is surely a necessary condition for accountability. If I take your hand and physically force you to pull the trigger of a loaded gun, you are not accountable for the harm caused. Voluntariness, however, is not sufficient. If I kill in self-defense, I have acted voluntarily, choosing to save my life at the cost of my assailant's. Yet I am not held responsible

TION, 21 (Joseph J. Costa ed., 1983); Martha R. Mahoney, Legal Images of Battered Women: Redefining the Issue of Separation, 90 Mich. L. REV. 1, 64 (1991).

${ }^{23}$ See, e.g., Cynthia K. Gillespie, Justifiable Homicide (1989).

${ }^{24}$ See Mahoney, supra note 22, at 34.

25 See Lenore E. WALKer, THe Battered Woman 55-70 (1979).

${ }^{26}$ See Anne M. Coughlin, Excusing Women, 82 CAL. L. REv. 1, 5 (1994) ("[T]he [battered woman syndrome] defense is objectionable because it relieves the accused woman of the stigma and pain of criminal punishment only if she embraces another kind of stigma and pain: she must advance an interpretation of her own activity that labels it the irrational product of a 'mental health disorder.'"); Elizabeth M. Schneider, Describing and Changing: Women's Self-Defense Work and the Problem of Expert Testimony on Battering, 9 WOMEN's RTS. L. REP. 195, 207 (1986) ("[T] $]$ he term 'battered woman syndrome' has been heard to communicate an implicit but powerful view that battered women are all the same, that they are suffering from a psychological disability and that this disability prevents them from acting 'normally.'").

${ }^{27}$ See Mahoney, supra note 22, at 42 ("This image [of passivity or pathology created by the battered woman syndrome defense] further promotes many cultural stereotypes, and may contribute to further stigmatizing of battered women and further denial by women of the dangers they face through domestic violence."); see also Coughlin, supra note 26; Schneider, supra note 26.

${ }^{28}$ I use the terms "accountable" and "ought to be held responsible" interchangeably in the discussion that follows. By "ought to be held responsible" I mean something different than "is responsible." In one sense the battered woman who kills her batterer is surely responsible for his death in that it is she who caused it. However, if the killing is either excused or justified, she may not be accountable for it. 
for that death. A normative evaluation of the act chosen is interposed between the voluntary act and the judgment of accountability. Because I am justified in killing my attacker when my own life is threatened, I am held neither morally nor legally responsible for my attacker's death.

According to some accounts, the justification or excuse that renders the actor not culpable affects the degree of voluntariness itself. ${ }^{29}$ Whether one sees the normative element of the inquiry as part of the analysis of voluntariness or as a distinct component is not significant to the analysis. What is important is that, except where the actor is unambiguously mentally ill, one must look at more than the cognitive component that I identify as "voluntariness" to determine whether the actor ought to be held responsible for his or her actions. To find the non-mentally ill person accountable for an act will also require a normative evaluation of the act chosen and the reasons for the choice.

I assume, arguendo, that the cognitive component of voluntariness has been satisfied in each case (the rock climber, the insulin refuser, and the battered woman who stays). I then examine whether the actor is accountable for the health-affecting choice involved. If she is not, this will be a strong conclusion. However, if she is, this will not end the inquiry; I simply will have determined that the actor can be held responsible for the given act, assuming that sufficient voluntariness is present. This leaves for someone else the difficult job of determining what counts as a freely willed action by a victim of ongoing spousal abuse.

Approaching the cases in this way, we see that what makes the rock climbing example an easy case is the fact that rock climbing is a pleasurable activity for those who enjoy it but not something one needs for an adequate life. One who decides to engage in rock climbing can be held responsible for the consequences it entails both because of the internal quality of will (the cognitive aspect of voluntariness) and because of the nature of the thing chosen (the normative evaluation). One is accountable for the consequences of one's decision to go rock climbing because giving up rock climbing is not a tremendous sacrifice.

\section{Accountability for Health}

\section{a. The Burden Account}

The State Farm analogy implicitly assumes that the diabetic who does not take insulin can justifiably be denied health insurance coverage because she is accountable for any deterioration of her health that results from this refusal. Assuming the diabetic voluntarily chooses to refuse (1987).

${ }^{29}$ For a complex and interesting account, see ALAN WERTHEIMER, CoERCION 287-306 
insulin, we need to determine what permits the move from this refusal to the judgment that the individual is accountable for her poor health prognosis. Interposed between the voluntary choice and the judgment of accountability is the claim that this person ought to take the insulin. What does this mean? Gerald Dworkin explores whether this "ought" derives from a general duty to care for one's health. ${ }^{30}$ There may be such a duty, but we do not need to make such a strong claim to understand why the insulin refuser is accountable. The insulin refuser is accountable for the inevitable decline in her health because the taking of daily insulin shots is not overly burdensome. ${ }^{31}$

We are looking for a way to distinguish the insulin refuser from the arthritis sufferer, assuming they deserve to be distinguished, as State Farm claims. The original argument proceeded by claiming that though it might not be fair to charge the arthritis sufferer more for insurance since he is not accountable for this condition, it is fair to charge the insulin refuser more because she is accountable for her resulting poor health. What distinguishes the two cases is both that the insulin refuser has control over the decline in her health (the voluntariness component of accountability) and that taking insulin is not overly burdensome (the normative component of accountability). ${ }^{32}$

The following examples will illustrate why both prongs must be satisfied in order to hold someone accountable for a decline in health. Imagine that someone can maintain good health only by staying indoors, completely immobile all day. He is able to walk, sit, and work but if he does so, he will damage his back in a way that will require expensive surgery. Compare this to the case of someone with a severe allergy to strawberries. If she eats strawberries, she will require hospitalization and, over time, if she continues to eat strawberries, she will require some form of expensive therapy. If control of one's health alone were enough for accountability (the "control test"), we would be justified in holding both people responsible for deterioration in health that results from moving, in the one case, and eating strawberries, in the other. This seems wrong.

We do not think that a person who must remain immobile to maintain health is accountable for the health decline that results from movement. Rather, the deterioration caused by engaging in basic life activities seems

${ }^{30}$ See Gerald Dworkin, Taking Risks, Assessing Responsibility, Hastings CENTER ReP., Oct. 1981, at 26.

${ }^{31}$ This argument explains why the insulin refuser is accountable for the difference only between what her health would be if she did take her insulin and what it is without this treatment. In other words, the insulin refuser is accountable only for the decline in her health that results from the refusal to take insulin.

${ }^{32}$ The normative evaluation depends upon a descriptive claim about whether the act in question is generally experienced as hard to resist. In other words, we need a descriptive account of the sorts of pressures and influences that the ordinary will can withstand. 
better described as simply happening to the person, like arthritis, than as being chosen, like the dangers of rock climbing. The immobility case seems more like the arthritis sufferer than like the insulin refuser or strawberry eater. This suggests that control alone is not enough for accountability. Since the difference between these two cases lies in the fact that in one case, safeguarding health requires great hardship, while in the other, health can be rather easily maintained, the comparison suggests that the degree of hardship required to safeguard health is the morally relevant factor.

In addition, when consistently applied, the control test is inherently unworkable. To see this, apply the control test to the immobility example. According to the control test, one is accountable for a decline in one's health if one could affect this decline and does not; one is not accountable, at least on this basis, if one could not. In the immobility example, the affected person can avoid a worsening in his health by remaining immobile. If he chooses not to do so, he is accountable for any health decline that results, according to the control test. However, he will still bear burdens caused by forces outside of his control. Although the health care costs associated with the underlying condition will be shared because having this condition is not within his control, according to the control test, the burden of remaining immobile itself will not be. The self-contradictory logic of the control test can be described more generally. If one must act to preserve one's health or be accountable for the consequences, then those whose health requires behavioral modifications will bear a burden (the modification) which results from a condition over which they do not have control (the underlying impairment). It is in the application of the control test that the test unravels-in applying it, one violates the principle on which it is based.

The control test for accountability therefore fails to justify any instances of insurance risk rating. Leaving health care costs where they fall, whenever someone can act so as to improve health, burdens those whose health requires more care than average-a burden resulting from an underlying condition which the individual does not control. In fact, the control test would not even justify the denial of coverage to the insulin refuser. Since the insulin refuser must take insulin or be denied coverage, according to this test, he must bear the cost of daily shots that results from diabetes, a condition over which he has no control. If the State Farm analogy is to get off the ground, we need an account that distinguishes the insulin refuser case from the immobility case, such that the first will but the second will not be held responsible for worsening health that each controls. What distinguishes the cases is the degree of burden that safeguarding health requires in each case.

Burdensomeness must be measured objectively, not subjectively. Remaining immobile is, objectively, a great burden. In addition, this objec- 
tive assessment of burdensomeness depends, in part, on context and culture. For example, we understand that driving carries a certain amount of risk of injury, even if carried out at reasonable speeds, while sober, and in good weather. Yet driving is also important and ordinary to most of us. Thus, if a person were injured in a car accident, leaving her with a disability requiring costly medical therapy (a preexisting condition for the purpose of insurance coverage in the future), we ought not view her as accountable for this condition. Though the risk of injury could have been avoided by not driving (i.e., the risk of injury is within the insured's control) and the dangers of car travel are well-known, since driving poses a reasonable trade-off of risks and benefits, giving up driving in order to safeguard one's health would be, objectively, a great burden.

This account of burdensomeness is similar in many respects to the familiar account of the reasonable person standard of negligence in tort. One acts negligently when one unreasonably puts others at risk. Similarly, one is accountable for one's poor health when one unreasonably puts oneself at risk. Conduct is unreasonable if the risk of harm thereby created is greater than the expected benefit. ${ }^{33}$ Since reasonableness is meant to be an objective standard, these harms and benefits cannot be assessed idiosyncratically.

Negligent conduct puts others at risk. Consequently, it makes sense to use an objective measure of burdens and benefits in assessing culpability in tort.' In contrast, risking one's health seems a quintessential self-regarding activity, thus raising the question why an objective conception of reasonable risk is appropriate here. For example, suppose Jack loves climbing. His life's goal is to reach the summit of Kilimanjaro. Although this is a highly risky activity, from his point of view the benefits outweigh the harms, when each is discounted by the probability of its occurrence.

From a subjective viewpoint, Jack acts reasonably. However, although climbing Kilimanjaro is very important to Jack, it is not very important if one does not share Jack's life plan and values. Thus, viewing Jack's action from the objective perspective transforms this subjectively reasonable act into one that is objectively unreasonable. Although taking care of one's health is a self-regarding activity, the question we are looking at is whether the insured is accountable for the danger undertaken to others in the risk pool with whom the risk of this activity will be shared. Because we are talking about sharing the costs of reasonable risk taking, the viewpoint of those with whom the risk taker will spread this risk must be accommodated. Therefore, the objective perspective must dominate.

${ }^{33}$ See Richard Posner, A Theory of Negligence, 1 J. Legal STud. 29, 32-33 (1972). 
The Christian Scientist diabetic poses a difficult case. Although following the tenets of that religion is only subjectively important, adhering to one's deeply held values is objectively so. ${ }^{34}$ Should the insurer be prohibited from denying coverage to the Christian Scientist insulin-refusing diabetic? In theory, the Christian Scientist diabetic should probably not be denied coverage because taking daily shots of insulin is objectively burdensome when doing so violates deeply held religious convictions. In practice, fine distinctions and subclassifications of this nature are likely to be too difficult to make operational. My project here is to sketch out the theoretical principles according to which we justifiably hold someone accountable for decisions that affect health. When these principles are enacted in policy, some accommodations will likely have to be made.

Therefore, one is accountable for a decline in one's health when the following two conditions are met: (1) one can affect one's health by doing or not doing certain activities; and (2) the doing or not doing of these activities is not overly burdensome. Immediately, we can see that this analysis renders the concept of accountability more difficult to apply than the control test. We are left with the problem of determining what counts as "overly burdensome."

Before proceeding to unpack the concept of "overly burdensome," I want to adopt a modification to the above approach that I borrow from Robert Veatch. ${ }^{35}$ Veatch claims that not all insureds who voluntarily engage in risky behavior ought to be denied insurance coverage. ${ }^{36}$ The example he offers suggests the need for an additional modification to the control equals accountability account. A firefighter voluntarily engages in risky behavior which makes him a substandard risk to the insurer. However, Veatch argues, the firefighter ought not to be denied insurance coverage despite the riskiness of his occupation because the firefighter serves an important social function..$^{37}$ Because fighting fires benefits us all, the increased risk that the firefighter faces ought to be spread through the community at large. Such risk spreading can be achieved by prohibiting risk segregation on the basis of this occupation. Adding Veatch's insight

\footnotetext{
${ }^{34}$ The climber case also can be recharacterized in a way that gives the subjective value objective importance. For example, it is objectively important that each of us fulfills our life project. This example is borrowed from Thomas Nagel, who explained the point in the following way. Some reasons are only subjectively important; however, the fulfillment of these "agent-relative reasons" can be objectively important. See THOMAS NAGEL, THE VIEW FROM NOWHERE 166-75 (1986). Using this recharacterization, Jack climbing Kilimanjaro is objectively reasonable. However, because it would be administratively difficult to ascertain reliably what each person's actual life project is, subsidizing risky individual life projects is justifiably avoided.

${ }^{35}$ See Robert M. Veatch, Voluntary Risks to Health: The Ethical Issues, 243 JAMA 50 (1980).

${ }^{36}$ See id. at 53.

${ }^{37}$ See id.
} 
to the two conditions previously established, we arrive at the following proposition. One is accountable for a decline in one's health if (1) one can affect one's health by doing or not doing certain activities; (2) the doing or not doing of these activities is not overly burdensome; and (3) the risky behavior does not serve an important social function.

The next step of the analysis is to apply this modified accountability approach to the case of the abuse victim who stays with her batterer. Assuming that she voluntarily chooses to stay, we must ask two questions. First, is leaving, the activity that is required to safeguard her health, overly burdensome? Second, does the risky behavior or activity serve an important social function?

\section{b. What Is Overly Burdensome?}

We do not yet have a good sense of which sacrifices for health and safety count as overly burdensome. In offering the insulin refuser example, State Farm seems to endorse the view that taking daily shots is not overly burdensome, although it surely is a burden. I agree. In offering the immobility example, I claim that remaining immobile requires too much of an individual. This person is not accountable for the health decline that results from moving to perform basic tasks. I propose the following test for what counts as overly burdensome: if the insured must refrain from a major life activity ${ }^{38}$ or forfeit an important attachment in order to protect her health, she ought not to be accountable for failing to do so.

The proposed test protects the choice of the battered woman to remain with her batterer from being used to categorize the battered woman as a substandard risk. Although her decision is voluntary, she ought not to be held responsible for the increased risk of injury she faces because of it. Few things in life are as important to people as their ties to family members and lovers. The abuse victim case is therefore more like the

\footnotetext{
${ }^{38} \mathrm{My}$ analysis of what ought to count as overly burdensome clearly owes a debt to the concept of disability found in the Americans with Disabilities Act (ADA). The ADA defines a "disability" as:

(A) a physical or mental impairment that substantially limits one or more of the major life activities of such individual;

(B) a record of such an impairment; or

(C) being regarded as having such an impairment.
}

42 U.S.C. § 12102(2) (1996).

Major life activities include "functions such as caring for oneself, performing manual tasks, walking, seeing, hearing, speaking, breathing, learning, and working." 29 C.F.R. $\S 1630.2(\mathrm{i})$ (1996). "[O]ther major life activities include, but are not limited to, sitting, standing, lifting, [and] reaching." 29 C.F.R. 1630 app. § 1630.2(i) (1996). "Mental and other emotional processes such as thinking, concentrating, and interacting with others are other examples of major life activities." EEOC Compl. Man. (CCH) § 902.3(b) (1995). 
immobility case than like the insulin refuser case. Just as staying immobile is a great sacrifice, leaving a lover or spouse is a great sacrifice, while taking daily insulin shots is not. Earlier I argued that refusing to spread the burden of immobility would be unfair because it would cause the heavy burden of remaining immobile to fall completely on one individual. Similarly, if we require that the abuse victim leave her lover in order to obtain health insurance, we leave the very heavy cost of forfeiting an intimate relationship entirely on her. What we are doing here is comparing burdens. For many people, giving up a relationship would be as difficult as giving up a major life activity.

One might object to the abstractness of this discussion. I have chosen to compare the burden of giving up a spouse or partner with the burden of giving up a major life activity. Because I believe that it is similarly hard to give up an intimate relationship as to give up a major life activity, I conclude that the abuse victim ought not to be held accountable for her decision to stay in the risky environment. This approach treats the domestic abuse victim as simply a person in a relationship. Moreover, it treats the relationship as just that-a relationship like any other. In other words, the analysis does not depend on, nor take account of, the particulars of the battering relationship. Why not?

I chose this mode of analysis to avoid the difficult and contentious issues that surround the psychological effects of abuse and the philosophical import of those effects on the ability to act voluntarily. If we assume that the abuse victim has the necessary cognitive capacity to act voluntarily in choosing to stay in the battering relationship, and yet conclude that she ought not to be held responsible for the increased risk she faces as a result, this conclusion will be especially forceful because its grounds will be acceptable to those who disagree about the psychological and philosophical import of ongoing physical abuse. ${ }^{39}$ Moreover, I believe it is important to recognize the similarities between the battering relationship and any other relationship. Relationships play important roles in people's lives. Even if those relationships are troubled and painful, they are difficult to sever. The approach this Article takes emphasizes the similarity between the burden that giving up the abusive relationship would impose on the abuse victim and the burden that anyone would feel when abandoning an intimate relationship.

Finally, were we to examine the burden of abandoning an abusive partner, the analysis would certainly change, but the result would not. The

${ }^{39}$ This strategy of avoiding the most contentious issue implicated in the analysis of an ethical question is familiar. For example, Judith Thomson's powerful defense of a woman's right to choose to end her pregnancy works by arguing that even we assume that the fetus is a person, the woman has no obligation to sustain the life of this person given society's general rejection of good samaritan obligations. See Judith Jarvis Thomson, A Defense of Abortion, 1 PhIL. \& PuB. AfFaIRS 47, 48 (1971). 
differences between the abusive relationship and the nonabusive relationship will cut both ways. The literature on domestic abuse suggests that the psychological effects of repeated battery by an intimate partner make it especially hard for the abuse victim to separate from her abuser. ${ }^{40}$ However, because the abusive relationship is of less value, certainly objectively and perhaps subjectively as well, than a nonabusive relationship, abandoning it may be easier for the abuse victim than abandoning a nonabusive relationship would be for someone else. It is difficult to say precisely how taking the fact of battery into account affects the burden of giving up an abusive relationship; however, looking at the issue concretely is unlikely to affect the result reached via the more abstract inquiry, and the more abstract inquiry has the additional virtues enumerated above.

Although both may voluntarily incur significant health risks, the abuse victim who stays with her batterer is not relevantly similar to the diabetic who refuses insulin because the abuse victim, like the person who must remain immobile to remain healthy, ought not be held responsible for exposing herself to heightened risk. Taking insulin is relatively easy. Leaving a spouse or lover, like giving up work or a major physical activity, is a large price to pay.

\footnotetext{
${ }^{40}$ See, e.g., WALKER, supra note 25 , at 49 . Walker applied the learned helplessness theory to battered women. According to Walker:

Repeated batterings ... diminish the woman's motivation to respond. She becomes passive. Secondly, her cognitive ability to perceive success is changed. She does not believe her response will result in a favorable outcome, whether or not it might. Next, having generalized her helplessness, the battered woman does not believe anything she does will alter any outcome, not just the specific situation that has occurred. She says, "No matter what I do, I have no influence." She cannot think of alternatives. She says, "I am incapable and too stupid to learn how to change things." Finally, her sense of emotional well-being becomes precarious. She is more prone to depression and anxiety.
}

Id. at $49-50$.

The "Walker Theory of Violence" describes the continuing cycle of three phases that characterize battering relationships: (1) the "tension-building" phase; (2) the "explosion or acute battering incident"; and (3) the "calm, loving respite." Id. at 55-70. During the third phase, which immediately follows the explosion, the battered woman is likely to return to her batterer, because it is then that he most resembles "the man she loves." Id. at 68 . Hoping that the third phase will last, the battered woman stays. See also OLA W. BarnetT \& Alyce D. LaVioletre, It Could Happen to Anyone: Why Battered WOMEN STAY 16-17 (1993). Others propose alternative explanations for why battered women stay. See DutTon, supra note 22, at 161-217 (proposing a more general theory of "traumatic bonding"); Mahoney, supra note 22, at 64-82 (offering the concept of "separation assault" to explain that violence directed at women who attempt to leave often prevents women from successfully leaving abusive partners). 


\section{c. Objections}

There is an important difference between the immobility and abuse victim examples. In the immobility case, the person involved must give up major life activities for his entire life. In contrast, the abuse victim is asked only to give up one particular relationship. She is not required to forgo relationships altogether throughout her lifetime. ${ }^{41}$ Perhaps the apposite comparison to the burden involved in the abuse victim case is that of someone whose medical condition requires that she forgo an important life activity for a period of time. If the burden involved in leaving a spouse or lover is equivalent to that of giving up a major life activity for five to ten years, it is not clearly so burdensome as to absolve the abuse victim of accountability for remaining with a violent partner.

But, is this modified comparison more apt? Romantic partners are not interchangeable. Saying that the abuse victim must only leave this particular partner but remains free to develop other relationships may not adequately take account of the powerful attachments that she has made to the particular partner. Giving up a particular loved one ex post may be more difficult than giving up all relationships ex ante.

This discussion raises another important objection. So far we have been looking at the decision to stay in a battering relationship and asking whether that choice imposes too heavy a burden on the battered woman. In so doing, we have made two significant assumptions. First, we have assumed that the relationship has been going on for a long time. And second, we have assumed that when the woman began the relationship she did not know that she would be battered. If both these assumptions apply, the analysis may focus on the narrow question of whether giving up a spouse or lover imposes too heavy a burden. However, if the relationship is new or if, though developed, the abuse victim entered the relationship knowing what she was getting into, the evaluation of her decision to stay becomes more complex. Below, we look at each of these related complications.

It is easier to stop a developing relationship than to end a deep and long-standing one. At the extreme, it is surely no great burden to curtail a budding relationship which begins with violence on the first date. But how long-standing must a relationship be before giving it up becomes overly burdensome? Although there is no bright-line rule, at some point in the development of a relationship, the partner becomes so important that leaving him becomes overly burdensome.

This evaluation may also depend on whether the abuse victim knows what she is getting into. Minor violence early in a relationship, at which

\footnotetext{
${ }^{41}$ This difference was suggested to me by David Luban.
} 
point leaving is not overly burdensome, may indicate more harmful violence to follow. Perhaps the woman who stays through early signs of trouble is precluded from claiming later when dangerous violence develops that it is now overly burdensome to leave. This decision depends in part on what it is reasonable to infer from certain forms of violent behavior that do not require medical care. Do men who throw chairs, pound walls, and slap and push in ways that do not require medical care generally come to punch and kick and assault in ways that do require such care? And ought we to expect women to know this and to make their choices accordingly? ${ }^{42}$ Martha Mahoney's description of the difficulty in drawing a clear line between the violent and the nonviolent marriage is helpful here. She relates the account of a social worker who, when speaking about domestic violence, is frequently asked why women stay. Mahoney's social worker replies:

"When should she have left? At what point? Maybe the time she watched while he smashed up the furniture?" A silence, a shock of recognition, falls over the audience. It is, relatively speaking, normal for a woman to watch a man smash up the furniture. Many of the women in the room have seen something like it-and called it "marriage," and not "staying."43

Some battered women may be accountable for staying-those in relationships in which the violence occurred early and was unambiguously indicative of dangerous violence to follow. But this category may encompass only a small number of cases. As the Mahoney account makes clear, it is often difficult to know how to interpret violent behavior. And by the time the violence is of the type clearly harmful to the woman's health, she may have formed a powerful attachment to her partner. Moreover, empathy for a partner's failings and forgiveness are laudable qualities that may be necessary for any relationship to endure. However, these same qualities may impede the battered woman's ability to leave.

In this Section, I began with the premise that the abuse victim voluntarily chooses to stay in a battering relationship. I then asked whether this choice renders the denial of insurance coverage to her justifiable. I concluded that if her relationship is a developed one and if there were not adequate signs of violence early on, the abuse victim who stays is not accountable for the decision to stay with her battering partner because

\footnotetext{
${ }^{42}$ The answer to the question may also depend on the number of nonviolent partners available. Statistics on the number of violent relationships vary. See Mahoney, supra note 22 , at 10 (asserting that statistics on domestic violence vary widely-for violence in marriage alone from $12 \%$ to $70 \%$ ). The more common domestic violence is, the less ability women may have to choose only nonviolent partners.

${ }^{43}$ Id. at 16.
} 
leaving imposes too heavy a burden on her. I would also add that because it is likely to be too difficult to identify correctly the subclass of abuse victims who do not meet the above two criteria, both those who knew early on that their partners were violent and abuse victims in new relationships ought to be afforded insurance coverage. Overprotection is better than denying coverage to those who are entitled to it. ${ }^{44}$

\section{d. Will Leaving Promote Safety?}

In asking whether the abuse victim who stays with her batterer is accountable for the risk of staying, we have been assuming that staying is the riskier course. Available evidence shows that leaving is often extremely risky as well. Mahoney reports that "[a]t least half of women who leave their abusers are followed and harassed or further attacked by them. In one study of interspousal homicide, more than half of the men who killed their spouses did so when the partners were separated." 45 While it may be difficult to say whether, over the long run, staying or leaving is riskier, it is certainly not clear that leaving is unequivocally the health-enhancing alternative. ${ }^{46}$

\section{e. An Important Social Function}

We must also consider whether the abuse victim who stays fulfills an important social function. If so, this provides an additional reason why she ought not be held responsible for any resulting decline in health.

Battered women who remain with abusive partners may do so because they believe that their children need fathers, that they will be unable to provide for their children themselves, or because they value marital commitment. Available data suggest that children are harmed by living in a violent household. ${ }^{47}$ However, the fact that women stay because of the

\footnotetext{
${ }^{44}$ If we conclude that some battered women are entitled to have the community share the costs associated with their high risk status, see discussion infra Part I.D, then the community has an obligation to provide this support. The unavoidable overinclusiveness of the remedy designed to fulfill this obligation is a cost, but one that must be borne to fulfill the duty identified.

${ }^{45}$ Mahoney, supra note 22, at 64-65 (citing George W. Barnard et al., Till Death Do Us Part: A Study of Spouse Murder, 10 Bull. Am. Acad. Psychiatry \& L. 271, 274 (1982)). Mahoney points out that often it is the decision to leave that triggers the escalation in violence. Id. at 65. See also Gillespie, supra note 23, at 152 ("[A] Virginia study of male spouse-murderers found that in all but one case, the killing came shortly after the wife had made it clear that she intended to end the marriage.").

${ }^{46}$ This point is further substantiated by the fact that insurers who deny coverage to abuse victims generally do not distinguish between those who stay in the battering relationship and those who leave. See, e.g., Gaines, supra note 5.

${ }^{47}$ See Mary McKernon McKay, The Link Between Domestic Violence and Child Abuse: Assessment and Treatment Considerations, 73 Child Welfare 29, 29 (1994)
} 
(probably inaccurate) belief that staying benefits children may matter morally. Moreover, if these women are right about their inability to provide for their children adequately, children may in fact be better off if the women remain in the violent homes.

Leaving itself can be fraught with danger. Space in battered women's shelters is limited ${ }^{48}$ and often available only for short stays. ${ }^{49}$ For some women without nearby networks of friends and family, there may be nowhere to go other than the street. Living on the street may be as dangerous as staying in the violent home, especially for children. Finally, abuse victims are most at risk from violent partners immediately following separation..$^{50}$ Since the decision to leave often precipitates violent attack, it is not clear that leaving promotes safety.

Moreover, politicians of both parties have recently flooded the media with encomiums on marriage and the two-parent family. ${ }^{51}$ Given this public commitment to the importance of this institution and the role it is thought to play in the healthy development of children, perhaps these same politicians have obligated themselves to support the decisions of those who attempt to fulfill these ideals.

\section{f. Perverse Incentives}

So far we have recognized the burden involved in leaving a partner and the social benefits that may be achieved if the battered woman stays in the relationship. Oddly, this discussion seems to suggest that it is a

(noting that children living in a family where domestic violence is present are 15 times more likely to be victims of child abuse than are those in families without episodes of domestic violence-between $45 \%$ and $70 \%$ of these children are abused). In addition to the direct link between spousal and child abuse, children living in families with domestic violence are also more likely to develop behavioral and emotional problems. See Maura O'Keefe, Adjustment of Children from Maritally Violent Homes, 75 FAmILIEs Soc'y 403, 403 (1994).

48 See Angela Browne, When Battered Women Kill 111 (1987); Gillespie, supra note 23 , at 150 .

${ }^{49}$ BROWNE, supra note 48 , at 111 . While battered women could also stay at regular homeless shelters, most do not permit children. See Nancy Rubin, America's New Homeless, McCalls, Nov. 1988, at 118, 119, quoted in Merle H. Weiner, From Dollars to Sense: A Critique of Government Funding for the Battered Women's Shelter Movement, 9 LAW \& INEQ. J. 185, 188 (1991).

${ }^{50}$ See supra note 45 and accompanying text.

${ }^{51}$ See, e.g., Vice President J. Danforth Quayle, Address before the Commonwealth Club of California (May 19, 1992) (transcript on file with the Harvard Civil Rights-Civil Liberties Law Review) (arguing that "the failure of the family is hurting America deeply ... A welfare check is not a husband. The state is not a father. It is from parents that children learn how to behave in society"); Stephanie Zimmermann, Gore Says U.S. Needs 'Father Friendly' Society; Raps Government During Visit Here, CHI. Sun-Times, May 5, 1996, at 3 (quoting Vice President Albert Gore, addressing the Family Resource Coalition's national conference, as noting that "[c]hildren without fathers are more likely to be poor, drop out of high school or become teenage parents"). 
good thing for the abuse victim to remain with the abusive partner. This is unintentional. Rather, this Article merely attempts to recognize that leaving is often extremely difficult and that staying is often chosen for morally worthy reasons. The Article traces and analyzes the normative significance of these observations.

Nonetheless, prohibiting insurers from denying coverage to battered women who stay with their abusers may create incentives at odds with the important public policy aim of encouraging battered women to leave. While a prohibition on insurer use of the abuse victim classification will not encourage battered women to stay, as they will not derive any benefit by staying, such a prohibition may fail to encourage battered women to leave. An insurance program that denied coverage to women who stayed in abusive relationships, while continuing coverage for those who left, could fulfill important public policy purposes by encouraging the desired action-leaving the abusers. One should note, however, that current insurance practices do no such thing. Battered women who leave are denied coverage along with those who remain in battering relationships. Because the insurer bases pricing and coverage decisions on its bottom line rather than on public policy objectives, there is no reason for the insurer to treat battered women who stay with their abusers differently than those who leave.

However, states could prohibit only the denial of insurance coverage to abuse victims who leave. ${ }^{52}$ Such a proposal attempts to incorporate possible incentive benefits. Would this be better than an outright ban? The analysis of burdens and responsibility indicates no. The partial ban would penalize victims who stay. If victims who stay ought not be held accountable for that decision because abandoning a partner is overly burdensome, then denying or charging extra for coverage on this basis is unfair. While it is laudable for public policy to encourage battered women to leave, that policy must operate by incentives, not penalties. In order to distinguish between an incentive and a penalty one needs a normative baseline. That baseline has been established by the discussion above. Because the battered woman who stays ought not be held responsible for the decline in her health that results from this decision, denying her coverage on this basis constitutes a penalty.

Moreover, other incentive effects may cut in the opposite direction. Battered women's advocates worry that the current insurer practice, if it is widely known, may discourage abuse victims from reporting abuse to police or medical professionals. ${ }^{53}$ This concern is shared by physicians

\footnotetext{
52 If such legislation were enacted, insurers would either adapt policy to this prohibition, denying coverage only to those who stay, or the insurer would no longer employ the abuse victim classification because doing so does not produce sufficient economic benefit. See infra notes $105-106$.

${ }^{53}$ See Examining Proposals to Prohibit Insurers from Denying Health Insurance Coverage, Benefits, or Varying Premiums Based on the Status of an Individual as a Victim
} 
who regret that if battered women are reluctant to tell their doctors about injuries, both women's health and the integrity of the doctor-patient relationship will be compromised. ${ }^{54}$ In addition, as a history of emergency room visits itself can cause the insurer to deny coverage to the abuse victim, current practice may work to keep abuse victims from seeking needed medical treatment.

\section{B. Inconsistent with Actuarial Fairness}

Some critics of insurer use of the abuse victim classification claim that denying insurance coverage to battered women is inconsistent with a commitment to actuarial fairness. For example, Illinois State Senator Bob Madigan (R-Lincoln) explained that "the goal" of legislation pending in that state "is to prevent insurers from making unfair assumptions about people simply because of their past." ${ }^{\prime \prime 5}$ Thus, in denying insurance coverage to battered women, insurers are, allegedly, not impermissibly discriminating between high and low risk insureds. Rather, Madigan contends, the use of the classification is rooted in prejudice that blinds insurers to the fact that battered women are not substandard risks.

This is an empirical claim that ought to be relatively easy to assess, at least as to those women who indicate to the insurer either directly or through their medical records that they have been abused. Does this subclass of people draw on the insurer's resources more than the average insured? It is the insurer who is most likely to be in possession of this data. Because insurers have a competitive incentive to test the assertion on which the classification rests, it is likely that this claim will not be supported by available data. A battered woman is a potential client. If an insurer determines that the battered woman poses a standard risk, it can offer her insurance at.standard rates, thereby gaining business and drawing a good risk away from a competitor.

This allegation is also unthreatening to the insurer. If the classification is not actuarially sound, the insurer's interest and the critic's interest will be in accord. Both will be in favor of modifying current practice.

of Domestic Violence: Hearings on S. 524, S. 1028, and H.R. 1201 Before the Senate Comm. on Labor and Human Resources, 104th Cong. 1 (1995) [hereinafter Examining Proposals: Hearings] (statement of Nancy Durborow, Health Projects Coordinator for the Pennsylvania Coalition Against Domestic Violence); see also State Officials Move to Aid Abused Women on Insurance, N.Y. Times, Mar. 19, 1995, at A30 (quoting Terry Fromson of the Woman's Law Project of Philadelphia as fearing that "[i]f victims have to come forward at the risk of losing their insurance they won't come forward and we [the battered woman's movement] will be set back 25 years"); see also Nightline, supra note 3 (interview of Deborah Senn, Washington State Insurance Commissioner).

${ }^{54}$ See Examining Proposals: Hearings, supra note 53 (statement of Timothy T. Flaherty, member of the American Medical Association's Board of Trustees).

${ }^{55}$ See Amy Bradshaw, Insurance Legislation Focuses on Abuse Victims, PANTAGraph (Bloomington, Ill.), Apr. 24, 1996, at A6. 
However, if its use is supported by sound actuarial data, the critic cannot object on this basis to the insurer's continued use of the classification. Yet, the critic is likely to remain unsatisfied, suggesting that lack of actuarial accuracy is not the actual source of a well-grounded objection.

Interestingly, while some critics claim that the abuse victim classification is not supported by available data, others point to the fact that abuse is the major cause of injury among women as evidence of the unfairness of the insurer's practice. ${ }^{56}$ In fact, it is common to see the classification described as "discrimination" while its actuarial accuracy is simultaneously acknowledged. For example, Minnesota Senator Paul Wellstone defends his proposed federal bill ${ }^{57}$ as necessary "to correct an abhorrent practice" of denying insurance coverage to battered women-a practice which he describes as "plain, old fashioned discrimination," "profoundly unjust and wrong." 58 Yet Wellstone, in the same press release, describes domestic abuse as "the leading cause of injury to women, more common than auto accidents, muggings, and rapes by a stranger combined" and as "the number one reason that women go to emergency rooms." ${ }^{\text {"If }}$ If the wrongful discrimination Wellstone abhors is not irrational discrimination, it is unclear from his statement what makes it wrongful. Because all insurer classifications are "discrimination," understood nonpejoratively, one must ask why use of this classification is "plain, old fashioned," "profoundly unjust[,] and wrong[ful]" discrimination. ${ }^{60}$

\section{Statistical Discrimination}

Assume that the use of the abuse victim classification is actuarially sound. The critic may object to it on the ground that the correlation between abuse victims and users of health care services is not strong enough. Not all battered women will make claims against insurers. The use of the classification will therefore generate some "false positives." Critics of the use of this classification may see this fact as morally troubling. In fact, some insurers who have recently modified their policies have done so in a manner that responds to this concern with overinclusiveness. For example, MetLife no longer asks about domestic violence except in extreme cases, in which case inquiry proceeds "on an individual basis." 61 Well-

\footnotetext{
${ }^{56}$ See infra note 59 and accompanying text.

${ }^{57}$ The Victims of Abuse Access to Health Insurance Act, S. 524, 104th Cong. (1996).

${ }^{58}$ Senator Paul Wellstone, Press Release, Mar. 19, 1996, available in 1996 WL 8784532.

${ }^{59} \mathrm{Id}$.

${ }^{60} I d$.

${ }^{11}$ Dana Coleman, Domestic Violence Victims' Insurance Rights Backed, N.J. LAw., Apr. 22, 1996, at 10.
} 
stone's epithet—old-fashioned discrimination—suggests that rating of abuse victims on a individual basis would be curative.

This preference for individualized inquiry is misplaced. First, so long as abuse victims as a group do use health care more than average, individualized examination of insureds will not help most abuse victims. Second, this preference for individualized treatment reflects a misunderstanding of the way that risk rating in insurance operates. An analogous confusion has surfaced in the debate about the propriety of insurer use of genetic information about insureds. Developments in isolating and understanding the significance of particular genes have raised questions about whether insurers ought to be permitted to use genetic information in underwriting and rating risks. For example, some critics of the use of genetic information find it more defensible for an insurer to deny coverage to someone already suffering from a disease than to someone who carries a gene that indicates likelihood of developing the disease later. ${ }^{62}$ The former seems to treat the person as an individual, albeit an individual with cancer, the latter to treat the person as a member of a group, persons with a genetic predisposition to develop cancer. This is an unhelpful distinction. In both cases the insurer is predicting the level of risk posed by the potential insured. The cancer sufferer is not certain to require health services, even if she is presently undergoing treatment. She may be hit by a bus tomorrow, obviating the need for health care. Moreover, some predictive markers used by insurers have high levels of reliability. The breast cancer gene (BRCA1) is said to be eighty-five percent penetranteighty-five percent of those who test positive for the gene will develop breast cancer. ${ }^{63}$ Information derived from genetic testing is not different in either the degree of certainty it provides or in the manner in which it treats persons than more traditional indicators used by insurers to predict morbidity. In the case of both genetic information and traditional predictors, potential insureds are treated simultaneously as individuals with the particular risk factors they have and as members of groups all with $\mathrm{X}$ risk factor. ${ }^{64}$

${ }^{62}$ See, e.g., Richard A. Bornstein, Genetic Discrimination, Insurability and Legislation: A Closing of the Legal Loopholes, 4 J.L. \& POL'Y. 551, 566-69 (1996).

${ }^{63}$ According to recent studies, a BRCA1 gene carrier has approximately an $85 \%$ risk of developing breast cancer by age 70. See D.F. Easton et al., Genetic Linkage Analysis in Familial Breast and Ovarian Cancer: Results from 214 Families, 52 AM. J. Hum. GENETICs 678, 698 (1993) (estimating an 82\% cumulative risk); Deborah Ford et al., Risks of Cancer in BRCA1-Mutation Carriers, 343 LANCET 692, 693 (1994) (estimating an 87\% cumulative risk).

${ }^{64}$ While some criticism of insurer use of genetic information is ill founded, good arguments can be made for banning its use. The claim that allowing insurers to use information derived from genetic tests will discourage testing even where there are identifiable medical benefits to be realized is clearly important to examine. I believe that the intuitive unease many people, myself included, feel about insurer use of genetic information elucidates moral problems inherent in health insurance risk rating. At present, 
Thus far, we have established that false positives do not make the use of a classification illegitimate. Fairness in insurance risk rating does not require a perfect correlation between classification and predicted variable. One may still claim, however, that use of the abuse victim classification is not correlated strongly enough with use of health care services to warrant its use. In order to make this claim, one must articulate a standard for how tight a correlation between two variables must be to justify the use of one as a proxy for the other.

At one extreme is the untenable view that a proxy which generates any false positives ought to be prohibited. At the other extreme is the insurer position that so long as the correlation between proxy variable and predicted variable is positive, use of that proxy is permissible. In practice, insurers are unlikely to use classifications which are very weakly correlated with above ayerage use of health care services. An insurer will employ a classification whenever the costs of identifying and segmenting the class of persons with the particular characteristic are outweighed by the economic benefits to be gained by doing so. Segregation benefits the insurer by disaggregating a subclass of high risk insureds from its general pool. The insurer can then reduce rates, gaining a competitive advantage. Thus, an insurer will use a classification correlated with above-average health care use when the costs of doing so, such as the loss of some high-risk customers or the expense of identifying possessors of the trait, are outweighed by the market advantage to be gained by attracting more standard risk insureds to its pool. ${ }^{65}$

The critic who claims that the abuse victim classification is unjustifiable because the correlation between abuse victim status and above average use of health care is too weak must provide a normative argument for a particular degree of fit between a proxy and its target. Steven Maitzen offers such a view. He suggests that statistical discrimination is justified when the social utility, including the cost to the insurer of employing a particular classification, could not be increased by further refinement of the classification. ${ }^{66}$ If one were to apply this test to the abuse

the number of "uninsurables" is relatively small, but as advances in gene identification continue, that number will grow. Increased knowledge will allow us to rank risks into increasingly differentiated categories. Therefore, instead of one large pool of standard risk insureds set off by small pools of substandard risks and "uninsurables," the populace will become increasingly stratified into distinct risk categories. My intuition is that the phenomenon of greater risk stratification will make more people see most risk rating in health insurance as unfair. A similar point is made by Moseley and his colleagues, who argue that the classification of more and more people as substandard risks will increase public demand for social insurance schemes. See Ray Moseley et al., Ethical Implications of a Complete Human Gene Map for Insurance, Bus. \& Prof. Ethics J., Winter 1991, at 71.

${ }^{65}$ See generally Abraham, supra note 16, at 64-100.

${ }^{66}$ See Stephen Maitzen, The Ethics of Statistical Discrimination, 17 Soc. ThEORY \& Prac. 23, 26 (1991). Because Maitzen uses "willingness to pay" as the measure of social 
victim classification, one would need to ask whether the insurer could more accurately predict which battered women will later require health care by also looking at a secondary factor. If so, the insurer should risk rate using both characteristics if a net gain in social utility would result.

I am unsure whether most classifications currently used by insurers would meet this test. In order to know, we need a method of measuring social utility-a difficult task. Moreover, because critics of the abuse victim classification are concerned only with its use, the nature of their complaint appears to be comparative. Therefore, the critic must show that the abuse victim classification is less strongly correlated with use of health care services than are other predictive classifications employed by insurers.

I know of no such data. However, even if the abuse victim classification were less strongly correlated with health resource use than other classifications used by insurers, the remedy suggested by this critique would be unlikely to satisfy critics. Suppose the abuse victim classification were weakly correlated with health services use, but the subclass of abuse victims who have obtained restraining orders against their batterers (a refinement of the classification) were strongly correlated with health services use. To the critics of the current practice, this "reform" is unlikely to be perceived as such. This suggests that the critics do not object to the classification because it generates too many false positives. If they did, a refinement yielding fewer false positives should be preferred. Since the refinement suggested above does not respond to what is problematic about the classification, uneasiness with current practice appears to have nothing to do with statistical discrimination. Its source must lie elsewhere.

\section{Prohibited Classifications}

There is one last twist on this objection to explore. Current law prohibits the use of certain classifications by insurers in underwriting and risk rating. For example, some states prohibit the use of race by insurers ${ }^{67}$ notwithstanding differences in life expectancy among the races. ${ }^{68}$ Moreover, some states also prohibit the use of classifications that are linked to

utility, any actual result will only be as just as the underlying distribution of resources in the society when it is applied.

${ }^{67}$ The prohibition appears in the state's Unfair Trade Practices Act. For example, Arizona prohibits risk classification based on race, color, creed, or national origin. See Ariz. REv. Stat. ANN. § 20-384(2) (West 1990).

Even where permitted, insurers claim not to use race in risk classification. See Leah Wortham, Insurance Classification: Too Important to be Left to the Actuaries, 19 U. MicH. J.L. ReForm 349, 365 (1986) (citing Nondiscrimination in Insurance Act: Hearings on S. 2477 Before the Subcomm. on Antitrust, Monopoly, and Business Rights of the Senate Comm. on the Judiciary, 96th Cong. (1980)).

${ }^{68}$ See Sandra Smith, Highlights of 1995 Vital Statistics, 111 Pub. Health Rep. 558 
already protected classes. For example, in some states insurers may not risk rate on the basis of family history of sickle cell anemia or results of genetic testing for the trait that causes this disease. ${ }^{69}$ This is because sickle cell anemia primarily affects African Americans.

The moral basis for singling out the particular traits currently afforded special protection from insurance classification by state law is unclear. While there is some overlap between these classes and those groups protected by antidiscrimination law, it is far from complete. For example, with few exceptions, insurers are permitted to risk rate on the basis for sex. ${ }^{70}$

(1996), available in 1996 WL 9871754 (describing differing life expectancies by race and gender).

${ }^{69}$ Seven states prohibit insurers from denying coverage or charging higher premiums on the basis that the applicant/insured has the sickle cell trait. See ALA. CoDE \$ 27-5-13 (1975) (Amended 1982) (health and disability); CAL. INS. CoDE $§ 101223.3$ (West 1996) (self-insured employee welfare benefit plans); CAL. INs. CodE § 10143 (West 1993) (life and disability); FLA. STAT. ANN. § 626.9706 (West 1996) (life); Fla. Stat. ANN. § 626.9707 (West 1996) (disability); LA. Rev. STAT. ANN. § 22:652.1 (West 1995) (life and disability); MD. ANN. CODE art. 48A, § 223 (1996) (life and health); MD. ANN. CODE art. 48A, $\S 223.1$ (1996) (prohibiting insurers, nonprofit health service plans, and HMOs from using a "genetic test or the results of a genetic test to reject, deny, limit, cancel, refuse to renew, increase the rates of, affect the terms or conditions of, or otherwise affect a health insurance policy or contract"); N.C. GEN. STAT. \& 58-51-45 (added 1975); N.C. GEN. STAT. § 58-58-25 (added 1975) (life); N.C. GEN. STAT. § 58-65-70 (added 1975) (health service providers); TENN. CODE ANN. § 56-7-207 (added 1988) (life).

Some of the laws will accomplish very little, however, in that they explicitly prohibit only the use of this risk factor where it is not actuarially sound. For example, the Louisiana statute includes the following addendum: "Nothing in the Subsection shall prohibit waiting periods, pre-existing conditions, or dreaded disease rider exclusions, or any combination thereof, if they do not unfairly discriminate." LA. REv. STAT. ANN. § 22:652.1 (West 1995).

${ }^{70}$ Montana is the only state to ban classification on the basis of sex in all types of insurance. MONT. CODE ANN. § 49-1-309 (1983), which provides in pertinent part:

(1) It is an unlawful discriminatory practice for a financial institution or person to discriminate solely on the basis of sex or marital status in the issuance or operation of any type of insurance policy, plan, or coverage or in any pension or retirement plan, program, or coverage, including discrimination in regard to rates or premiums and payments or benefits.

Three states have nominally banned sex-based classification. See Mo. AnN. STAt. $\S 375.995$ (West 1991) (forbidding sex-based classification "except to the extent such restriction, modification, exclusion, or reduction [of terms] is a result of the application of rate differentials permitted under the insurance laws of this state"); VT. STAT. ANN. tit. 8, § 24724 (1993) (forbidding charging different rates on the basis of sex, "however, nothing in this subdivision shall prevent any person who contracts to insure another from setting rates for such insurance in accordance with reasonable classifications based on relevant actuarial data or actual cost experience in accordance with section 4656 [now replaced by section 4686] of this title"); WASH. REv. CODE ANN. $\$ 48.30 .300$ (West 1993) ("[T]hese provisions shall not prohibit fair discrimination on the basis of sex . . when bona fide statistical differences in risk or exposure have been substantiated.”).

Three states have banned sex-based classifications in the issuance of insurance policies, but not in rates or premiums. See MD. ANN. CoDE. art. 48a, § 234A (1992) 
The arguments in Parts I.C and I.D present new reasons to afford the abuse victim classification special protection. Here, we are looking at the current web of law affording protection to certain classes to see if a consistent application of the principles plausibly undergirding these prohibitions would point toward protection for the abuse victim. Clearly no such protection is offered explicitly. The best argument for abuse victim protection is as follows. Just as risk rating on the basis of sickle cell anemia is prohibited because this disease predominantly affects African Americans, so too ought the abuse victim classification to be banned because battery predominantly is perpetrated against women.

The problem with this approach is readily apparent. Sex itself is not treated as is race by most states, as most permit the use of sex in risk rating. ${ }^{71}$ In fact, when regulators in some states have attempted to interpret their state's version of the Unfair Trade Practices Act (the statute that delineates permissible rating and underwriting practices) as prohibiting the use of sex as a category in risk rating, these regulations have been struck down by courts. ${ }^{72}$ "Unfair discrimination," proscribed by statute, has been given a narrow reading, prohibiting only actuarially unsound pricing and underwriting practices.

Federal law has curbed this state permissiveness in limited ways. Title VII of the Civil Rights Act of 1964 has been interpreted to reach employer-provided pension and annuity plans, thereby prohibiting the use of sex-based tables for either contributions or disbursements. ${ }^{73}$ In general,

(including the limitation that "[a]ctuarial justification may be considered with respect to sex"); Minn. Stat. AnN. § 72A.20 (West 1986); N.M. Stat. AnN. § 59A-16-13 (Michie 1984).

In addition, Pennsylvania has interpreted the Equal Rights Amendment to its state constitution to require unisex rating in auto insurance. See Hartford Accident and Indem. Co. v. Insurance Comm'r, 482 A.2d 542 (Pa. 1984) (holding that automobile insurer's gender-based rates violated Pennsylvania's Equal Rights Amendment); Bartholomew v. Foster, 541 A.2d 393 (Pa. Commw. Ct. 1988), aff'd, 563 A.2d 1390 (Pa. 1989) (holding that an automobile insurer's gender-based rates violated Pennsylvania's Equal Rights Amendment, even assuming that such rates were actuarially sound). The Pennsylvania National Organization for Women challenged the Bartholomew decision, contending that charging men and women the same rates for automobile insurance amounts to overcharging women, since women drive fewer miles than men. See Pennsylvania Nat'l Org. for Women v. Commonwealth, 551 A.2d 1162, 1166-67 (Pa. Commw. Ct. 1988). The court upheld its earlier decision and found that the automobile insurers' practice of charging identical rates to men and women did not violate the Equal Rights Amendment. Id. at 1167.

${ }^{71}$ One notable exception is automobile insurance. As others have remarked, it is striking that states would single out car insurance, an area where women are benefited by sex-segregated insurance, as the lone field in which unisex rating is required. See, e.g., Jill Gaulding, Race, Sex, and Genetic Discrimination in Insurance: What's Fair?, 80 CoRNELL L. REv. 1646, 1663-64 (1995).

72 See id. at 1662 n.104 (citing cases in Florida, Louisiana, and Massachusetts).

${ }^{73}$ See Arizona Governing Comm'n for Tax Deferred Annuity and Deferred Compensation Plans v. Norris, 463 U.S. 1073, 1084 (1983) (holding "[t] he use of sex-segregated actuarial tables to calculate retirement benefits violates Title VII whether or not the tables reflect an accurate prediction of the longevity of women as a class"); City of Los Angeles 
when sex-based actuarial tables are used, life insurance is cheaper for women than for men and annuities are cheaper for men than for women. Prohibiting the use of sex-based tables flips the value of these benefits: men receive a greater benefit from the unisex-priced life insurance, while women receive a greater benefit from the unisex-priced annuity.

When insurance is provided as a benefit of employment, Title VII forbids the employer from using sex-based rating. Health insurance is not greatly affected, however, because employer-provided health insurance is generally not subject to individual risk rating. The individual insurance market, where most underwriting and risk rating takes place, is untouched by this body of law. Title VII is an employment statute, not an insurance statute.

\section{Third Party Action}

In this Section we examine whether it makes a difference that the battered woman is denied insurance coverage because of what someone else has done to her. We will consider the following claim: the abuse victim is relevantly different from the arthritis sufferer in that no person caused the arthritis while the increased risk that the battered woman faces is due to her batterer's actions. Why should this matter? Imagine that a person suffers a debilitating disability which is the result of a botched routine medical procedure. Under the current health insurance system, he is likely to be uninsurable. ${ }^{74}$ Moreover, if he is employed by a small business which provides employee health insurance, he may render the entire group uninsurable. Alternatively, the insurer may simply exclude from coverage any medical care or costs stemming from this disability. ${ }^{75}$ If this seems more unfair than comparable treatment of a person whose disability has a physiological etiology, this is because one attributes significance to the distinction between "human-caused" and "natural."76 It is as if one believes that while people must bear the burdens fate deals, they ought not to suffer those with a distinctly human cause.

The claim that causal origin is morally significant cuts in the direction opposite from the view examined in Part I.A. That Section asked whether it is more justifiable to deny coverage to abuse victims than, say,

Dep't of Water and Power v. Manhart, 435 U.S. 702 (1978) (holding that requiring female employees to make larger contributions to pension funds than otherwise similarly situated male employees violated Title VII of the Civil Rights Act of 1964). Because women, on average, live longer than men, the larger contributions to the pension fund made by the women in Manhart provided men and women with the same expected value.

${ }^{74}$ See infra note 12 and accompanying text.

75 See Deborah A. Stone, The Struggle for the Soul of Health Insurance, 18 J. Hzalth PoL. PoL'y \& L. 287, 306 (1993) (explaining the difference between the individual and group markets for insurance and the insurer's options to exclude based on risk status).

${ }^{76}$ I use the term "natural" to mean attributable to other than human cause. 
arthritis sufferers, because abuse victims are responsible for their poor risk status. That claim was rejected because the heavy burden of abandoning a partner clears abuse victims of accountability for staying. Here, we examine whether it is less justifiable to deny coverage to abuse victims than to arthritis sufferers because abuse victims need health care due to another person's actions while the arthritis sufferer's need has no human cause. This Section will argue that this distinction is untenable and therefore carries no moral significance.

Reliance on the distinction between human-caused and natural differences in risk status is commonplace in arguments about the defensibility of various insurance practices. For example, participants in the debate in the early 1980 s over the justifiability of sex-segregated actuarial tables by pension and annuity providers made much of it. Pension and annuity plans offered as part of employee benefit packages came under scrutiny because Title VII of the Civil Rights Act of 1964 prohibits "discrimina[tion] against any individual with respect to his compensation, terms, conditions, or privileges of employment, because of such individual's . . . sex."77 Defenders of sex-segregated tables argued that the tables were justified because the difference in life expectancy between men and women has a biological basis. ${ }^{78}$ Critics replied that the observed differences in life expectancy were more properly attributable to environmental factors such as smoking and job stress and therefore that classifications based on sex were impermissible. ${ }^{79}$ Participants on both sides of the debate agreed that this difference was significant.

The most plausible defense of the normative distinction between human-caused and natural is that acts of individuals are partly caused by social structures. Therefore, the community shares responsibility for the mistakes, negligence, and culpable actions of its members. "Acts of God," by contrast, are largely independent of social agency. If the community shares responsibility for harm caused by its members, the costs of such harm should be shared as well. This can be accomplished by disallowing insurance risk segregation for human caused high-risk factors attributable to someone other than the insured.

If we apply this argument to the example above, we see that the doctor's negligence is partly society's fault. Perhaps the physician was improperly trained. Perhaps hospital supervision was subpar. Perhaps wouldbe physicians are inadequately screened by the professional association in the state in which the doctor was certified. This type of argument is

7742 U.S.C. § 2000e-2 (1994).

${ }^{78}$ See Lea Brilmayer et al., Sex Discrimination in Employer-Sponsored Insurance Plans: A Legal and Demographic Analysis, 47 U. CHI. L. Rev. 505, 539-59 (1980); see also Richard Kimball, Reverse Sex Discrimination: Manhart, 1979 AM. B. Found. Res. J. 83.

${ }^{79}$ See Brilmayer et al., supra note 78 , at 540-59. 
strongest in cases, like this one, where the community has asserted regulatory authority over the activity involved. Because the community licenses physicians and protects a monopoly over the practice of medicine, it bears great responsibility for the "product" that results.

The community's responsibility for battery is significantly more attenuated. However, the argument for it would proceed as follows. Society is responsible for creating and sustaining a moral climate wherein violence against women is acceptable. An ideology_-A man's home is his castle"-makes domestic battering seem more defensible than attacks by strangers. Because the community tolerates domestic battery, it continues; therefore, the community should share the victim's loss. Regulations on insurance classification can accomplish this by spreading the increased insurance cost that domestic abuse victims face among all insureds.

The claim that human-caused losses justify risk spreading more than naturally caused losses because communal responsibility for human acts can be easily deconstructed. At present, the community allocates money for medical research in accord, partially, with the number of people afflicted with a given disease. Consequently, the breast cancer sufferer benefits from the large investment of communal resources devoted to understanding and effectively treating that disease. ${ }^{80}$ By contrast, people afflicted with rare conditions get far less benefit from public research funding. ${ }^{81}$ The person whose poor health is caused by a rare disease for which there is no adequate therapy available may require costly ongoing care, thus making her a substandard risk from the insurer perspective. Yet, it is unclear whether this is a natural or human-caused state. Because our response to our environment will determine in part what is in fact left to fate, the distinction between fate and human agency will be of limited use.

While there may be no non-normative line between injustice and misfortune, there are normative reasons for treating some sorts of suffering as one and other sorts as the other. The question to ask is whether there are reasons to treat poor health as a misfortune while treating being likely to be attacked as an injustice. At present our society treats health as a matter of fortune-if someone is ill or disabled, we lament his or her fate but do not view the illness or disability as being grounds for entitlement to communal aid. ${ }^{82}$ In Part II of this Article we will examine how

${ }^{80}$ See Marcia Angell, Caring for Women's Health-What is the Problem?, 329 NEw ENG. J. MED. 271 (1993) (detailing NIH's \$197 million budget for cancer research).

${ }^{81}$ See Alison Stuebe, Project Helps Families Cope with Rare Illnesses, Wash. Post, Aug. 31, 1995, at M1 (explaining how victims of rare diseases, often called orphan diseases because they receive little funding, are often left to raise funds for research on their own).

${ }^{82}$ The Medicare and SSI programs act as limitations on this claim. However, because one's right to benefits under these programs arises upon a showing of poverty, it is not 
one's view about the correctness of this moral attitude contributes to whether one sees the general practice of insurance risk rating as defensible. In this Section, we are concerned only with exploring the reasons for treating being at high risk for domestic violence differently than being at high risk for illness. While we do not yet recognize an obligation to provide health care to all, our society does recognize a duty to provide protection from crime. If this protection is adequately provided and is distributed on a fair basis, then being attacked is a misfortune. However, if protection is inadequate or unfairly distributed, then in being attacked, one suffers injustice. ${ }^{83}$ It is to these questions that we will now turn.

\section{Crime}

A battered woman is a crime victim. Perhaps denying coverage to her is meaningfully different from denying it to the arthritis sufferer because her condition results from the criminal act of another. Critics of the abuse victim classification seem to allude to such a claim in complaining that women are suffering "abuse [at] home ... [and then being further] victimized by insurance companies." 84 Of course the battered woman is not the victim of the insurer in the same way as she is the victim of her batterer. Absent a prohibition like those included in the statutes at issue, the insurer may legally deny coverage to a potential insured based on a history of domestic abuse. However, the abuser is not legally permitted to batter his partner. ${ }^{85}$ The repetitive use of "victim" by the critic suggests that, in the critic's view, the abused woman is entitled, morally if not legally, note to be denied coverage on this basis and that this entitlement is tied to her status as a crime victim.

The battered woman is denied insurance coverage because she will probably utilize health care services disproportionately. This is because women who have been battered in the past are likely to be battered in the future, thus sustaining more injuries that require medical treatment. ${ }^{86}$ Since battery is a crime, the abuse victim is denied health insurance

illness or disability that is the triggering factor for mutual aid, but illness plus poverty or disability plus poverty.

${ }^{83}$ Of course, the assailant violates the rights of his victim, thereby treating her unjustly. Our focus here is on whether society's failure to prevent or deter the attack also constitutes an injustice.

${ }^{84}$ Health Insurance: Hearings, supra note 5 (statement of Sheila Wellstone).

${ }^{85}$ Some critics of the law's protection of abused women claim that such inadequate protection is tantamount to permission to batter under the law. See Kathleen Waits, The Criminal Justice System's Response to Battering: Understanding the Problem, Forging the Solutions, 60 WASH. L. REv. 267, 271 (1985).

${ }^{86}$ The insurers' actuarial data support this claim. In this Part, as in Part I.C of the Article, I assume the accuracy of the insurers' data. If the data are inaccurate, the insurer itself has good reason to stop using the classification. See discussion supra Part I.B. 
coverage because she is likely to be a future crime victim. In the following Sections, I argue that because the state has an obligation to provide protection against crime on a fair basis, a warranted suspicion that the State has failed in this duty provides a good reason for the community to share the costs of the resulting injuries.

\section{The State's Obligation to Provide Protection from Crime}

The State has undertaken the obligation to protect citizens from crime, but not, for the most part, to protect them from disease and carelessness. ${ }^{87}$ Denying coverage to the abuse victim because she is likely to be attacked in the future may be meaningfully different from denying coverage to the cancer victim if the risk the abuse victim faces results from a State's failure to fulfill its protection obligations. Although the incidence of crime, particularly violent crime, appears to be falling, ${ }^{88}$ the pledges of protection are not abating. Both Democrats and Republicans call for more prisons, more police, tougher sentences, swifter justice, and fewer avenues to challenge legal determinations of guilt. ${ }^{89}$ In fact, it is from those who are generally most in favor of limited government that the strongest call for crime protection originates.

Our society has committed itself to providing protection from crime as one of the central functions of the State. However, the uncontroversial claim that the State should protect members against crime does not tell us whether there is a minimum of safety that must be achieved, nor does it tell us how protection ought to be distributed. Use of the battered woman classification is problematic, according to this argument, only if the battered woman's risk results from inadequate state protection. The insurers' data tell us the battered woman is less safe than the average

${ }^{87}$ The Clean Air and Water Acts, and other public health measures, are instances of government taking some responsibility for disease prevention. Similarly, by enacting safety regulations, such as the Occupational Safety and Health Act (OSHA), government undertakes some responsibility to protect citizens from carelessness. The government has not, however, undertaken a general obligation to protect us from disease and carelessness as it has undertaken a general obligation to protect us from violent crime.

${ }^{88}$ The incidence of violent crime fell four percent from 1994 to 1995 , and the number of murders fell eight percent in the same period. See Serious Crime Continues Decline; Figures Fell in 1995 for 4th Year in a Row, but Teen Violence Rises, BALTIMORE SUN, May 6,1996 , at 1A (citing FBI report released on May 5, 1996).

${ }^{89}$ Bob Dole claimed that the U.S. needs to build more prisons in order to "put space between hard-core criminals and law-abiding Americans." Crime and Prevention, BosToN GloBE, June 1, 1996, at 10. President Clinton, in his 1994 State of the Union Address, exhorted that "we must take serious steps to reduce violence and prevent crime, beginning with more police officers and more community policing ... you're going to be given the chance to give the American people another 100,000 [police officers], well trained, and I urge you to do it." President William Clinton, State of the Union Address, reprinted in The State of the Union Address: "Let Us Resolve to Continue the Journey of Renewal," WASH. Post, Jan. 26, 1994, at A12. 
insured, but not that she has been afforded less than her fair share of protection. A general crime protection obligation entails no specific obligation to spread the costs incurred by those who are less safe than average (by prohibiting the abuse victim classification, for example), unless citizens have a right to be equally safe.

The fact that a person is more likely than average to be victimized by crime does not by itself demonstrate that this person is inadequately protected or that the protection resources of the State are unfairly distributed. We begin with the uncontroversial assertion that protection afforded by the State ought to be provided on a fair basis. It is not clear, however, what fairness requires. Perhaps it requires that the same amount of protection money be spent on each member of the political community. Or instead, fairness may permit distribution of protection based on need (more money on those more vulnerable to attack) or distribution based on effectiveness (more money spent on preventing those rights violations that can be deterred most effectively) or some combination of these principles and/or others. In order to determine whether the abuse victim is getting her fair share of protection, we need to know which among these principles or others or which combination of them defines a fair distribution of protective resources.

Two additional issues complicate the assessment. First, the purpose of the protection afforded by police surveillance and prosecutorial vigor is to decrease the number, perhaps weighted by degree of seriousness, of those rights violations that are proscribed by law. However, increasing protection also runs a risk of violating rights. For example, abandoning the "reasonable doubt" standard of guilt in criminal cases for a less demanding standard would increase safety both by increasing deterrence and by decreasing the number of criminals on the street. However, safety would simultaneously decrease because of the greater likelihood of unjust conviction and punishment. Similarly, constitutional prohibitions on arrests, searches, and seizures make apprehension and prosecution of criminals more difficult, thereby compromising safety, but also prevent rights violations of another kind. This trade-off can be seen at the individual level as well: few would want a permanent bodyguard, though having one would increase safety, because of the privacy invasion involved.

Therefore, in order to know whether the abuse victim is unfairly underprotected, we must know whether increasing protection through police surveillance and more vigorous prosecution would decrease the likelihood that her rights will be violated. If an increase in protection brings a greater likelihood of violating her civil liberties than it offers security from crime, more protection will not yield more safety.

Second, fair distribution of protection may not require equal safety even if increased protection yields decreased rights violations. If factors other than the level of protection contribute to variable crime rates, shift- 
ing extra protection to high-crime areas may waste resources without much safety increase. This argument is familiar from the debate over the just distribution of health care resources. ${ }^{90}$ If hopelessness, lack of opportunity, and other effects of poverty contribute to high crime, then a fair distribution of protective resources probably does not require that everyone be equally safe.

There is a fourth reason why below-average safety may not indicate underprotection: personal irresponsibility regarding safety. Surely a drug dealer or gang member, both of whom are likely to be especially at risk for assault, is not entitled to be made as safe as the average person through increased protection. Drug dealing and gang membership are risky activities for which one ought to be held individually accountable.91

In sum, the fact that someone faces an above-average risk of assault is undeterminable. The insurers' data tell us that the domestic abuse victim is less safe than the average insured, but this fact does not allow us to conclude that the battered woman is inadequately protected.

\section{a. Garbage in, Garbage Out}

However, there remain good reasons to suspect that inadequate protection may be partly to blame. Sexist attitudes and blindness to violence perpetrated in the home have likely caused inadequate police response, lax prosecution of batterers, and lenient sentencing of convicted offenders, ${ }^{92}$ all important elements of State protection. Attitudes, however, are changing. How much these factors contribute today to the fact that domestic abuse victims are less safe than the average insured is hard to know.

It is, I believe, the suspicion that domestic abuse victims have been inadequately protected that lies at the root of the intuition that domestic abuse victims ought not be denied insurance coverage on this basis. Although the above discussion shows that it would be extremely difficult to prove that a person or group of people is not getting a fair share of protection services, we can draw inferences from some obvious facts. There has been inadequate police response to domestic violence in the past which may continue today. Prosecutors have been loath to pursue these claims. Since the State has an obligation to protect citizens and to do so on a fair basis, the incursion of this illegitimate principle of distribution (tolerance of domestic violence) is problematic. Whichever of the plausible alternative conceptions of fair distribution of protective resources is right, the inclusion of an illegitimate principle is likely to have skewed

\footnotetext{
${ }^{90}$ See, e.g., Norman Daniels, Just Health Care 52-55 (1985); Charles Fried, RIGHT AND WRONG ch. 5 (1978).

${ }^{91}$ See discussion of accountability supra Part I.A.

${ }^{92}$ See Waits, supra note 85.
} 
the result-garbage in, garbage out. In other words, we do not need to know precisely what a fair distribution of protection would be in order to determine that some schemes are unfair. Since an inappropriate tolerance for domestic violence has been part of the input, we can justifiably suspect injustice in the output. ${ }^{93}$

\section{b. Rushdie Example}

A comparison may help to show the work being done by the suspicion that an illegitimate distributional principle (unjust tolerance for domestic assault) has skewed the provision of protection. Imagine an American Salman Rushdie on whom a beating sentence has been imposed by religious leaders, rather than a death sentence. Were he to seek private health insurance, he would presumably be denied coverage or charged a high rate. Both Rushdie and the abuse victim are more likely than average to need medical services in the future because both are more likely than average to become the victims of criminal assault.

Rushdie's case demonstrates that the fact that someone is more likely than average to be victimized by crime by itself does not warrant the conclusion that he is unfairly underprotected. Even with special protection (bodyguards and a safe house, for example), Rushdie may remain especially vulnerable. Indeed, special protection arguably affords him more than his fair share of protective resources. In Rushdie's case there is no reason to suspect inadequate protection due to illegitimate principles of distribution. We have no reason to think that Rushdie, or people like him (those whose work has offended Islamic fundamentalists), has been underprotected. Hence, the Rushdie case is importantly different from the abuse victim case. Society should partly share the costs of the abuse victim's high-risk status because we suspect that an illegitimate tolerance for domestic violence has skewed the distribution of protective resources.

\section{Expressive Significance}

The intuition of the critic that use of the abuse victim classification is wrong derives, I believe, from another source as well. In a sense, the

${ }^{93}$ Although this argument seems similar to the argument considered and rejected in Part I.C (third-party action), the two differ in important respects. In Part I.C, I rejected the assertion that the societal sexism which may have caused both inadequate police protection as well as the batterer's disposition to batter could be the source of a communal responsibility for the harm caused by domestic abuse. In this Section, I argue that the same suspicion that sexist attitudes have influenced the distribution of protection is important but for a different reason. It is not because this is a human-caused problem that it warrants a human-caused solution. Rather, it is because the state has a clear, discrete, and uncontroversial obligation to provide security and to do so on a fair basis that the suspicion of an illegitimate influence on the distribution of protection is morally relevant. 
insurer's reliance on the actuarial fact that the abuse victim is more at risk for assault than average itself seems offensive. In using data about domestic abuse like data about cancer morbidity, the insurer is seen by the critic as asserting that battery and cancer are morally equivalent. But, does the insurer's policy actually have the expressive significance asserted and if so, does this provide a reason to ban its use by insurers?

The insurer treats the abuse victim and the cancer sufferer the same (denying them both health insurance coverage), but treating $A$ and $B$ the same is not equivalent to asserting that they are the same in all respects. Rather, the insurer's equal treatment of A and B rests only on the claim that the differences between $\mathrm{A}$ and $\mathrm{B}$ do not provide reasons to treat them differently in the insurance context. Therefore, if there is expressive significance in the insurer's comparable treatment of disease and abuse victim status, it rests on a misguided impression of what that comparable treatment signifies.

Nonetheless, the insurer's practice may be seen by others as resting on the view that there are no morally relevant differences between being beaten up and getting cancer. The insurer's practice may then cause the same harm as an act that really did express the view that domestic abuse is no greater injustice than cancer. ${ }^{94}$ Appearances themselves can be normatively significant. ${ }^{95}$ The currently proposed legislation would send a countermessage. ${ }^{96}$ In requiring that abuse victims not be segregated from risk pools, the legislation sends a message of community solidarity with battered women. Moreover, treating domestic abuse differently from disease expresses the view that while disease may be merely a misfortune, battery is an injustice.

In sum, the proposed legislation is necessary primarily because it is likely that an illegitimate tolerance for domestic violence is in part to blame for the fact that the abuse victim is a poor health insurance risk.

\footnotetext{
${ }^{94}$ In the beginning of the discussion about whether it makes a difference that the abuse victim is denied coverage because she is likely to be the victim of crime in the future, I posed this question by asking whether being at high risk for future assault should be viewed as a misfortune or an injustice. We have so far concluded that it depends. If there is reason to suspect inadequate protection, then being at high risk for assault may be injustice. If there is no reason to suspect inadequate protection, then this risk status may be merely a misfortune. These conclusions should not be taken mistakenly as equivalent to the claim that the assault by the batterer itself is not an injustice: clearly, the batterer wrongs his victim. That does not necessarily mean that the insurer wrongs her too. The case of the American Salman Rushdie makes this clear. An assault on Rushdie would clearly be an injustice; the denial of insurance coverage to him by the insurer would not be.

${ }^{95}$ See Deborah S. Hellman, The Importance of Appearing Principled, 37 ARIz. L. Rev. 1107 (1995).

${ }_{96}$ In defending the proposed federal legislation, Senator Wellstone explained: "The proposed bill [treats] domestic violence as the crime that it is-not a voluntary risky behavior that can be easily changed and not as a pre-existing condition." Senator Paul Wellstone, Press Release, supra note 58.
} 
Moreover, the opportunity that passage of this legislation offers to send a clear message of solidarity with abuse victims and recognition of the injustice done to them by their batterers provides an additional reason to support the legislation. ${ }^{97}$

\section{E. Other Remedies}

The above analysis explains why the abuse victim ought not bear the costs of her above-average risk of future assault. It does not explain why the cost should be spread via this particular means: prohibiting the abuse victim classification. There are two alternatives. First, make the batterer pay the victim's increased insurance or health care costs. Alternatively, spread the cost to all through a tax-and-transfer system. Each of these solutions will be considered below.

\section{Batterer as Payer}

Battery is not only a crime; it is also a tort. The victim of a tort can sue the tortfeasor for the full extent of the damage caused by the tortious conduct. In the case of the abuse victim, damages clearly include medical expenses incurred as a result of the assault. They should also include the difference between what it will now cost the victim to insure herself (if insurance is available) and what it would have cost her if never attacked. In theory, since tort law allows the victim to recover compensation for all harm caused, there is no need for the State to step in with a supplemental remedy.

In practice, full recovery is unlikely to be forthcoming. First, battered women rarely sue their batterers in tort. The batterer and victim may form a single economic unit such that a tort suit would provide no help. Even if the victim has left the batterer, tort recovery may simply deplete resources available for child or spousal support. Moreover, since the lifetime value of increased insurance or medical costs may be substantial, many batterers would lack adequate resources to compensate their victims even if suits were brought. Finally, there may be psychological barriers to seeing the abusive lover as someone one should sue.

${ }^{97}$ There may be other reasons to support the proposed legisiation. For example, if one believes that the practice of risk rating itself is ethically problematic, then the legislation may be justified as a first step toward the abandonment of this practice. Part II, infra, addresses these concerns. 


\section{State as Payer}

Alternatively, the cost of insuring abuse victims could be borne by taxpayers. The arguments we have examined in this Section explore when and why the cost of being at high risk for assault ought to be shared with the community. But the abuse victim legislation would spread this cost only among other insurance consumers. ${ }^{98}$ If the cost ought to be borne by all, it may be unfair for one segment of the community to bear it entirely.

Thus far I have not offered an argument for why the community's responsibility to share the cost of the abuse victim's high-risk status ought to be met in the manner proposed by the abuse victim legislation. By prohibiting the use of the abuse victim classification and, in the case of the stronger bills, by prohibiting classification on the basis of the effects of domestic abuse, the legislation will force a subsidization of the abuse victim's special costs by other insureds in the pool. As a result, insurance consumers will bear the cost that ought to be borne by the community as a whole. This seems unfair.

However, cost spreading through the insurance markets is not illsuited to its goal. Only the uninsured would not share in the communal obligation..$^{99}$ At present, about fifteen percent of the population is uninsured. ${ }^{100}$ If we are worried about the number of people for whom health care is unavailable, this fifteen percent ought to cause us great concern. However, if we are worried about spreading the cost of insuring the abuse victim fairly, fifteen percent does not represent a significant mismatch between target and actual contributors. If we look at who among us is uninsured, the unfairness of paying for the risk spreading in this manner is further ameliorated. The working uninsured are generally at the low end of the income bracket. ${ }^{101}$ The nonworking uninsured are unlikely to have significant taxable income. Therefore, the difference between financing this cost spreading through a tax-and-transfer program and financing

${ }^{98}$ Although the legislation itself simply prohibits insurers from using the abuse victim classification, its effect will be to pass the extra costs of insuring the abuse victim at standard rates through to other insurance consumers.

${ }^{99}$ The employees of large companies, students, and others who are already provided insurance via large group-rated plans already contribute to providing coverage for the domestic abuse victims among them. Consequently, this group would be unaffected by the proposed legislation.

${ }^{100}$ Cost, Number of Insured Still at Issue under Health Reform Bill, EBRI Suggests, Pens. \& Ben. DaILY (BNA), May 20, 1996 (citing Employee Benefit Research Institute Issue Brief No. 173, Health Insurance Portability: Access and Affordability); see also Employee Beneft Research Inst., Sources of Health Insurance and CharacTERISTICS OF THE UNINSURED (1996).

${ }^{101}$ In the late 1980s, three-fourths of the working uninsured earned less than $\$ 10,000$ per year. See Lawrence D. Brown, The Medically Uninsured: Problems, Policies, and Politics, 15 J. Health Pol. Pol'y \& L. 413, 414 (1990) (citing U.S. Gen. Accounting OfFice, HeAlth INSURANCE: AN OVERVIEW OF THE WORKING UNINSURED (1989)). 
it through increased health insurance premiums is minimal. Those who will be exempt from contributing if cost spreading is achieved through increased insurance costs (i.e., the uninsured) would contribute little if the same goal were achieved via a tax-and-transfer scheme. ${ }^{102}$

Nevertheless, one might still argue that surely it is preferable to achieve the desired cost spreading through a direct tax-and-transfer system rather than by co-opting the insurer as cost spreader. I agree that such a policy would be preferable. However, it is unlikely to be politically feasible. The proposed legislation is a justified second best alternative.

The sort of indirect taxation achieved through legislation of the type we are considering has been criticized because it obscures the real cost of the program or policy enacted. A bill proposing a tax increase to compensate domestic abuse victims for the extra insurance or health care costs they bear has the advantage of making visible both its objective and its cost. In contrast, the legislation we are considering hides that cost. Even for those observers who understand that the cost associated with this change will be passed along to other insureds, the salience of this fact may be muted. Such obfuscation has been criticized as harmful to democratic legitimacy (we do not know what we are approving) as well as to fiscal responsibility (we support programs which we would not support if we fully understood how much they cost).

These are powerful and important criticisms of off-budget mechanisms of enacting policy. While I agree that these arguments make direct tax-and-transfer preferable to off-budget mandates, I do not think the arguments, in particular the democratic legitimacy argument, are necessarily as damaging to off-budget programs as they initially seem. Below I offer what I take to be a plausible account of self-paternalism which explains and legitimizes the use of off-budget policymaking.

A voter may have two conflicting desires. First, she desires lower taxes. Second, she desires that certain programs be enacted-for example, a school lunch program. These are both first-order preferences. In addition, she recognizes that these two first-order preferences conflict because a school lunch program is financed from tax revenue. Understanding this conflict, our voter has a second-order preference that her wish to finance the school lunch program will take precedence over her desire for lower taxes. This second-order preference simply orders her first-order preferences. Based on this account, our voter should simply support the school lunch program financed directly from tax revenue.

However, our voter suffers from weakness of the will. Though she does have a second-order preference for her wish to support school lunches

${ }^{102}$ The tax mechanism for cost spreading also has the advantage of offering some progressivity. However, given that the current tax code is not highly progressive, this benefit is not of great significance. 
to trump her desire for lower taxes, she also recognizes that she is likely to respond negatively to legislators who support tax increases even though she supports the programs these tax increases finance. She will vote her pocketbook rather than her conscience. Recognizing her own irrationality, she may believe it would be good for legislators to enact the programs she supports via mechanisms that make the costs of these programs less obvious. Because she views her own reaction to the tax increases necessary to finance the programs she supports as contrary to her considered judgment, she would like the temptation to give in to her desire for lower taxes to be removed. If this story is plausible, it gives our voter a reason, ex ante, to support the use by legislators of off-budget policymaking.

The desirability and legitimacy of off-budget policymaking is a large, complicated, and interesting topic that I will leave to others. Suffice it to say that a direct tax-and-transfer method of financing the cost of insuring the domestic abuse victim is the preferred policy choice. However, the abuse victim legislation recently enacted and currently pending is a justified second best. It is justified both because the set of insurance consumers and the set of taxpayers is relatively well-matched and because the threat to democratic legitimacy is not clearly established.

\section{Adverse Selection}

A tax-and-transfer system is also preferable to insurance regulation because regulation will skew market choices. Regulation mandating crosssubsidization of some insurance purchasers by others will induce some members of the protected class to overpurchase insurance and some members of the remaining population to underpurchase. This will occur because the standard rate for coverage charged to the standard risk will be slightly higher under the regulated regime than otherwise because some substandard risks (battered women) will be included in the general pool. As a consequence, some standard risk consumers will be priced out of the market. In addition, some battered women who would not purchase health insurance at the actuarially accurate rate will purchase it at the standard rate because this rate constitutes a bargain. The combined effect of these two trends will be to render the pool of standard risks less healthy. This process is known as adverse selection. ${ }^{103}$

In theory, under a cross-subsidization regime, adverse selection will be a continuing process. The insurer, left with a less healthy pool of standard risks, is forced to raise rates, thereby precipitating a second wave of defection of good risks and overpurchasing by poor risks, and so on. In practice, however, mandated cross-subsidization of a small class of

\footnotetext{
${ }^{103}$ See Abraham, supra note 16, at 15.
} 
insureds is unlikely to produce significantly destabilizing results. Since such cross-subsidization will be required by law, all insurers will be similarly affected. Thus, the standard risk consumer has only two choices: pay the inflated cost or self-insure. Some of the uninsured population will choose not to purchase insurance because they are healthy, they expect to remain so, and insurance is expensive. However, it is unclear how pricesensitive this population will be. While regulation is less desirable than a tax and transfer system, the market distortion caused by regulation is unlikely to be serious enough to warrant rejecting the abuse victim legislation.

\section{Moral Foundations of Risk Rating}

We now turn to risk rating itself. We have considered whether the abuse victim classification is different from other insurance classifications in order to determine what can be said about the recently proposed and enacted legislation without evaluating risk rating itself. We have determined that available arguments justify the legislation. Our suspicions that the abuse victim may be getting less than her fair share of protection, combined with the desire to counter the image produced by a practice that treats battery and disease the same, provide good reasons to enact the abuse victim laws. In considering the several examples used in Part I, readers may have been struck by unexplored similarities. Rather than ask whether the abuse victim is different from the arthritis sufferer or cancer victim, one might have thought that all three ought not to be denied coverage - and for the same reasons. We now turn to those reasons.

A full-blown argument in support of, or against, the practice of insurance risk rating is beyond the scope of this Article. The goal of this Part is to provide three frameworks through which to understand the bases of disagreement about risk rating. A clearer understanding of the moral foundations of the opposing views about risk rating will provide useful insight that will advance the ongoing debate.

The principle of actuarial fairness (AFP) that underlies the practice of risk rating announces itself as a moral principle: it is fair for insurance prices to reflect actuarially sound predictions of risk for individual insureds. According to this principle, actuarially based pricing is fair, not simply actuarially fair but truly fair. This view is supported by two claims: one grounded in the rights of low-risk individuals; the other based on a rejection of alleged obligations to high-risk individuals. Both will be considered below. 


\section{A. Desert and Entitlement: Rights of Low-Risk Individuals}

Risk rating is fair if low-risk individuals are entitled, morally speaking, to reap all possible benefits of their good health. As Norman Daniels explains, this claim is based on the controversial assumption that "individuals are entitled to benefit from any of their individual differences, especially their different risks for disease and disability." 104 In most instances, good health or lack of disability is not itself deserved. Those who believe that risk rating is fair claim that the undeservedness of good health does not vitiate the entitlement to use and benefit from this health as one wishes. It is my good health, after all.

Of course one can do many things that are health enhancing, such as exercising or eating a low-fat diet, and many things that are harmful to health, such as smoking. The discussion in this Section focuses on those aspects of health that are clearly outside of one's control. The principles that ought to guide how health affecting lifestyle choices are treated is laid out in Part I.A. Health is a product of both choice and luck. This Section addresses how the role of luck in one's health ought to be viewed.

The actuarial fairness principle could be grounded upon a very strong claim. An actuarial accuracy purist might assert that fairness requires that each insured pay premiums precisely equivalent to her individual expected loss. The more modest and plausible view is that fairness requires that low-risk insurance consumers be permitted to join together in insurance pools and thereby benefit from their good health. The purist view is implausible because it would give the insured a moral claim to pricing reflecting then-current information about risk. Moreover, the view would be shunned by insurers themselves as it would require vast and costly changes in current practice.

The pricing system employed by insurers today is both more rough and more complex than the purist AFP would require. The insurer's pricing practice works as follows. An insurer will segregate a given class of insureds using an accurate predictive classification when the costs associated with doing so are less than the anticipated profit. Costs include the cost of gathering information about the correspondence between the characteristic in question and the likelihood of needing medical care, the cost of distinguishing those insureds with the characteristic from those

${ }^{104}$ Norman Daniels, Insurability and the HIV Epidemic: Ethical Issues in Underwriting, 68 MilbaNK Q. 497, 504 (1990). Daniels believes that understanding the controversial nature of the claim underlying the defense of actuarial fairness is important in itself because arguments in defense of it often treat actuarial fairness as an unassailable moral principle. "Demonstrating that the strong assumption about individual differences is deeply controversial at the level of the theory of justice is not a refutation of the argument from actuarial fairness, but it does give us good reason not to accept the assumption without a convincing argument." Id. at 506. 
without it, and the cost of lost business associated with false positives (insureds with the characteristic who do not in fact pose an increased risk for the insurer). The benefit to be gained is the market share the insurer is able to acquire by offering competitively lower rates to the new lowrisk group now segregated from the previous class. A look at the current individual insurance market shows that only some characteristics meet the above test. The market sanctions the use of some predictive characteristics such as age, gender, health history, and alcohol and tobacco use ${ }^{105}$ but not others such as diet, exercise habits, and sexual promiscuity. ${ }^{106}$ Individuals with different actual risk profiles are grouped together as standard or substandard risks.

Since insurers are guided by economic self-interest rather than actuarial purity, compliance with the pure AFP would necessitate drastic reform of current practices. ${ }^{107}$ Moreover, if the costs of complying with this fairness principle are high, as they are likely to be, conforming to it may not be economically feasible. Finally, as some commentators have pointed out, the proper understanding of this version of the AFP may require that insurers invest in technologies that would permit more accurate predictions about expected loss, ${ }^{108}$ thus making this demanding principle even more so.

More importantly, the pure AFP is an unlikely candidate for a moral principle as it assumes an entitlement not only to the good or bad fortune of one's own body, but also to the currently available level of information about risks. According to this interpretation of the AFP, fairness requires premiums based on perfect actuarial accuracy given available information. The insurer cannot risk rate only using economically efficient classifications, it must charge each individual insured an actuarially accurate price. It is this entitlement to the benefits of a particular information level that makes the purist version of the AFP an extravagant proposition.

We turn now to the weaker, but more plausible, version of actuarial fairness. This is the claim that low-risk insureds have a right to enjoy their low-risk status by joining only with other low-risk insureds in insurance

${ }^{105}$ Robert J. Pokorski, Principles of Insurance and Risk Classification, in THE Potential Role of Genetic Testing in Risk Classificatron (Genetic Testing Committee, American Council of Life Insurance ed., 1989).

${ }^{106}$ These characteristics are known to affect health but are not used by insurers in risk rating. $I d$.

${ }^{107}$ Interestingly, those defenders of the current practice who call on the strong version of the AFP do not seem to recognize that it would require a vast overhaul of current practice. See, e.g., Karen A. Clifford \& Russel P. Inculano, AIDS and Insurance: The Rationale for AIDS-Related Testing, 100 HARV. L. REv. 1806, 1808 (1987) (arguing that "[a]n insurance company has the responsibility to treat all its policyholders fairly by establishing premiums at a level consistent with the risk represented by each individual policyholder").

${ }^{108}$ See Daniels, supra note 104, at 508. 
pools. Fairness, according to the impure AFP, requires that the low-risk individual be able to take advantage of her good fortune rather than having to dilute it by sharing the misfortune of those who are high risk. ${ }^{109}$ We are here examining a moral right, not a legal right. The low-risk insured would have no colorable legal challenge to legislation restricting her ability to contract with other low-risk insureds on the terms they choose. The end of the Lochner era marked the end of the aggressive protection of economic liberties. The legitimacy of both state and federal restrictions on the terms on which parties may contract is well-established. ${ }^{110}$

In most instances, the traits that make someone a good insurance risk are not earned or deserved by those who hold them. Although health habits are contributing factors, the dominant forces affecting health outcomes are outside of personal control. The traits on which risk rating operates such as prior medical history, family medical history, and blood pressure are, as John Rawls would term them, "arbitrary from a moral point of view." "11 Whether low-risk individuals have a moral right to benefit from this good fortune (by joining only with others who also are at low risk of drawing from insurance pools) depends on what moral significance lies in the fact that the traits determining health are themselves under served. ${ }^{112}$ There are two dominant views.

According to the first view, associated with Rawls, if qualities of persons are not themselves deserved, then one does not deserve the benefits these qualities make possible. ${ }^{113}$ Rawls is chiefly concerned with the legitimacy of such benefits as high wages and social status. However, his view can be easily translated to the insurance field. Because good health is undeserved, the relatively inexpensive insurance it makes available is similarly undeserved. As a result, persons have no entitlement to actuarially accurate pricing.

\footnotetext{
${ }^{109}$ Perry Beider identifies the interest at stake as a liberty interest: "the freedom of those in certain actuarial classes to voluntarily contract among themselves, via insurance agents, for the maximum mutual benefit." Perry C. Beider, Sex Discrimination in Insurance, 4 J. APPLIED PHIL. 65, 70 (1987).

${ }^{110}$ See generally West Coast Hotel Co. v. Parrish, 300 U.S. 379 (1937) (sustaining a state's regulation of women's wages).

111 JoHN RAWLS, THEORY OF JUSTICE 311-12 (1971).

112 As discussed earlier, where the trait selected is one for which the individual is accountable, risk rating is much more clearly defensible. See supra Part I.A.

${ }^{113}$ According to Rawls, "no one deserves his place in the distribution of native endowments, any more than one deserves one's initial starting place in society," and therefore no one has a legitimate claim to the benefits these endowments make possible. RAwLS, supra note 111, at 104. Because the benefits that flow from talent are not deserved, the individual's claim to them has no moral standing for Rawls. Rather, he sees the goods produced by talent as communal assets to be distributed in accord with his principles of justice. Thus, according to Rawls's difference principle, we ought "to regard the distribution of natural talents as a common asset and to share in the benefits of this distribution." Id. at 101.
} 
If I am not entitled to benefit from my good health, I have no moral right to join only with other healthy individuals in an insurance pool. According to Rawls, without desert, entitlement derives only from the legitimate expectations created by the social structure itself. ${ }^{114}$ Society may arrange that structure, ordering how people benefit from their endowments, in any manner consistent with the demands of justice. Therefore, low-risk insureds have no right to pool with whomever they choose other than that created by the insurance laws and regulations.

A competing view disputes the link Rawls draws between desert and entitlement. According to Robert Nozick, the fact that traits like talent and good health are undeserved does not mean their possessors are not entitled to the benefits they yield. ${ }^{115}$ For Nozick, "it needn't be that the foundations underlying desert are themselves deserved, all the way down." 116 So long as one does not violate another's rights, one is entitled to the goods obtained through the use of undeserved qualities or capabilities. ${ }^{117}$ It is interference with the freedom to make use of health or talent that requires justification. ${ }^{118}$ Therefore, the low-risk individual is entitled ${ }^{119}$ to join with other low-risk persons, pooling their low risks, in order to purchase health insurance at relatively low prices.

We now can see the point of disagreement. We can all agree that, at least in most cases, low-risk individuals do not deserve their good health. Does the moral arbitrariness of this fact mean that low-risk insureds are not entitled to the benefits that flow from good health? Or instead, is it interference with the low-risk insureds' ability to benefit from good health that requires justification? Those struck by the moral arbitrariness of good health are likely to believe that risk rating is unjustified in most cases. Since the healthy do not deserve the benefits health makes possible, they have no legitimate claim of entitlement to them. This rationale supports community rating and single-payer schemes. Those who are struck by the idea that my talents, fortunes, and experiences are my own and thus that the community needs a powerful justification to interfere with my ability to use and enjoy these traits, are likely to believe that any restraint on my ability to join with whomever I wish in insurance schemes constitutes an

${ }^{114} I d$. at 311.

115 Robert Nozick, ANARchy, State, and Utopia 225 (1974).

116 Id.

${ }^{117}$ For Nozick, a person is entitled to what he has so long as he has acquired these goods legitimately-either by taking them from the realm of "unheld" things in the right way ("justice in acquisition") or by properly acquiring them from someone else who holds them legitimately ("justice in transfer"). Id. at 150-53.

118 Id. at $160-64$.

${ }^{119}$ Nozick stresses the distinction between desert and entitlement. While natural assets are not deserved, so long as they are not unjustly acquired, the persons holding them "are entitled to them, and to what flows from them." Id. at 226. 
infringement of liberty requiring a defense. This rationale supports the utilization of risk rating by private insurers.

\section{B. Misfortune and Injustice: Obligations to High-Risk Individuals}

The fairness of actuarially accurate insurance pricing can also be viewed from the perspective of our obligations to those in poor health who either pay more for, are denied, or have limited access to health insurance today. These high-risk individuals bear both the burden of the poor health or disability itself and the high cost of insurance, if it is available. Just as the good health of the low-risk individual is in most cases undeserved, the poor health of the high-risk individual is also, in most cases, undeserved. But is it merely a misfortune? We use the terms "misfortune," "fate," and "act of God" to designate suffering that society owes no duty to alleviate, although acts of beneficence are to be admired and encouraged. "Injustice" we reserve for hardship that should have been prevented or remedied. Inquiry into the obligations owed to the unhealthy thus requires distinguishing between misfortune and injustice.

We can ask this question (misfortune or injustice?) about both poor health itself and about the derivative burdens it engenders, including expensive health insurance. Initially it seems that poor health is paradigmatic misfortune. No one is to blame for it-it is just bad luck. But there is much that can be done to alleviate the suffering of the sick or disabled-for example, medical therapy, health care attendants, nicer homes, and better vacations. Lives can be improved both through services that alleviate the cause of the suffering and through cash or services that compensate for bad health in other ways. The question whether to provide these will always raise issues of justice. As Francis Snare explains, "Of course nature's initial distribution is just a brute fact. But the claim that we ought to let that distribution lie (and indeed protect it!) is a claim of distributive justice." 120 There is no non-normative way to distinguish between misfortune and injustice. Rather, in calling some hardships misfortune, we endorse a particular distributive scheme-one that will leave that hardship where it falls.

Where should one to draw the line between misfortune and injustice? Disagreement about how and where to draw this line replays the philosophical disagreement discussed above. The view that the person in poor health who is unaided by the political community suffers an injustice is analogous to the claim that one has no legitimate entitlement other than that accorded by the social structure to one's natural capabilities and the goods those capabilities engender. Rather, qualities such as health and

${ }^{120}$ Francis Snare, Misfortune and Injustice: On Being Disadvantaged, 16 CANADIAN J. PHIL. 39, 51 (1986). 
talent can be seen as communal assets, ${ }^{121}$ and the distribution of the benefits these assets provide are thereby properly the subject of distributive justice.

Similarly, those who believe that the brute fact of the initial distribution ought to carry normative significance endorse a view that is the flip side of the Nozickian position described above. If entitlement can flow from traits that themselves are undeserved, this is because the initial distribution does not itself require justification. This is another way of saying that this initial distribution is a matter of fortune rather than justice.

The language of misfortune and injustice thus gives us another way of capturing the disagreement over risk rating. On one side is the view that good and bad health and the benefits and burdens that go with them are instances of good and bad fortune. If so, then nothing is owed to the misfortunate to ease these hardships. On the other side is the view that how society reacts or responds to the initial distribution of benefits and burdens is a question of justice.

\section{Defining Our Community}

A third way of understanding the disagreement over the justifiability of insurance risk rating is as a discussion about what kind of a community we want to be. As Deborah Stone explains, a community defines itself, in part, through its practices of providing mutual aid. ${ }^{122}$ If we reject risk rating in favor of community rating or a single-payer scheme, we identify illness and disability as bases for the provision of mutual aid in our society. On the other hand, if we maintain our current use of risk rating (at least in the private insurance market), we reject illness and disability as triggering instances for mutual aid. ${ }^{123}$ Thus, the debate about whether the actuarial fairness principle ought to govern health insurance pricing is a debate about whether ours is a community that is committed to the provision of aid to those who are sick or disabled.

This way of framing the question avoids talk of rights and obligations. Instead, it poses the question as an issue of communal self-definition. In deciding whether to accept or reject health insurance risk rating, we ask what kind of a people we want to be.

${ }^{121}$ RAWLs, supra note 111 , at 101-02.

122 Stone, supra note 75 , at 289-90.

${ }^{123}$ Medicaid and Medicare make poverty and old age, when combined with illness or disability, conditions that trigger aid. 


\section{The Legislative Response}

In the past two years there has been a flurry of legislative activity aimed at restricting insurer ability to use abuse victim status in underwriting and risk rating. ${ }^{124}$ Laws have been enacted in sixteen states that curb the use of this classification. In addition, bills have been introduced in twelve other states and in both houses of Congress. ${ }^{125}$ There is tremendous variation among these laws and bills, both in their strength and in the harm they propose to remedy. In what follows, I set out the five types of bills introduced at both the federal and state levels. The majority of the state legislation, both pending and enacted, is weak. While the federal legislation is generally stronger, none of it has been enacted. ${ }^{126}$

The weakest type of legislation prohibits only irrational discrimination against abuse victims. Use of the abuse victim classification is prohibited only where it is not actuarially sound. For example, the recently enacted New York law provides that no insurer "shall solely because a person is or has been a victim of domestic violence" deny or limit coverage in various ways. ${ }^{127}$ To do so solely because of a prospective insured's status as an abuse victim is prejudice. However, if the insurer denies or limits coverage because abuse victims are at higher risk than average insureds (i.e., both because the person is an abuse victim and because abuse victims have bad claim histories), the insurer will not run afoul of the New York statute. This permission is made explicit by the following provision of the bill:

The prohibitions [above] ... shall not preclude an insurer from taking any of the actions described [above] ... so long as such insurer relies on underwriting criteria reasonably related to the physical or mental condition of a person, their property or claim history and the decision was based on sound underwriting and actuarial principles . . . ${ }^{128}$

Of the sixteen enacted bills, five are of this type, as is the proposed legislation from Washington state. ${ }^{129}$

${ }^{124}$ See supra notes 7-8.

${ }^{125}$ See supra notes 8-9.

${ }^{126}$ See supra note 9.

${ }^{127}$ N.Y. INS. LAW § 2612 (McKinney 1996) (emphasis added).

${ }^{128} \mathrm{Id}$.

${ }^{129}$ See Fla. STAT. Ch. 626.9541(1995); Iowa Code § 507B.4(1995); ME. REv. Stat. ANN. tit. 24A, § 2519-B (West 1996); N.H. REv STAT. ANN. § 417 (1996); S. 5436, 54th 
The most common bill type nominally forbids rational discrimination against abuse victims, but is weak and ineffectual. I call this type the category prohibition (CP). While these bills forbid use of the abuse victim category both where it is actuarially sound as well as unsound, they simultaneously permit the substitution of another predictive variable to get at the same class of people. Remember, the insurer charges the abuse victim more for coverage, or denies coverage, where permitted because the insurer believes the abuse victim is more likely than average to make a claim on the insurance pool. Either the abuse victim will be assaulted again, thereby requiring medical services, or the prior assault leaves her with an ongoing medical condition that will require future care. If she is charged more because the insurer believes she is more likely than average to be assaulted in the future, the $\mathrm{CP}$ will not prevent the insurer from continuing to screen her out if it can find another reasonably good predictor of the likelihood of future assault. In other words, the CP prohibits only the use of the abuse victim classification, not adverse treatment of those the insurer thinks are likely to become abuse victims, so long as they are identified in another way. Since most abuse victims are currently identified by medical records, which indicate repeated injuries and/or repeated visits to emergency rooms, using the medical histories alone may serve the insurer's goals almost as well as using the prohibited abuse victim classification. ${ }^{130}$

A good example of this type of law is the legislation recently enacted in Indiana. The law provides that the insurer may not deny or limit coverage "because the individual has been, is, or has the potential to be a victim of abuse," but the insurer is not prohibited from "adjusting premiums ... on the basis that the individual has a physical or mental condition or medical claims history."131 Seven of the sixteen enacted state bills only weakly prohibit adverse treatment of abuse victims by insurers in precisely this way. ${ }^{132}$ In addition, seven of the twelve proposed bills

Leg., 1st Sess. (Wash. 1996). The language of the Florida statute is a bit unclear. However, I believe it belongs in this category. See also H.R. 1920, 104th Cong. (1995) (federal bill introduced on June 22, 1995 by Representative Molinari (R-N.Y.)). The language of H.R. 1920 makes it unclear whether it prohibits only irrational discrimination or instead whether some weak prohibition on rational discrimination (like the category prohibition type of bill, described below) is intended.

${ }^{130}$ See Andrea Gerlin, States Adopt Measures to Protect Abuse Victims From Insurers' Bias, WALL ST. J., Feb. 8, 1996, at B11.

${ }^{131}$ S.B. 306, 109th Leg., 2d Sess. (Ind. 1996).

${ }^{132}$ H.B. 2236, 42d Leg., 2d Sess. (Ariz. 1996) (covering life and disability insurance only); A.B. 1973, Regular Sess. (Cal. 1995); ALS 193, 1995 Leg., 1st Sess. (Conn. 1995); S.B. 306, 109th Leg., 2d Sess. (Ind. 1996); S.B. 444, 76th Leg., 1st Sess. (Kan. 1996); S.B. 339, 1996 Leg., Regular Sess. (Md. 1996); S.F. 1815, 79th Leg., 2d Sess. (Minn. 1996). 
follow this form ${ }^{133}$ as does the federal bill introduced in the House of Representatives by Representative Susan Molinari. ${ }^{134}$

Bills that only prohibit the use of the abuse victim classification reflect a conception of the wrong to be righted as the singling out of abuse victims by insurers for special treatment. The harm lies in the fact that one's status as an abused woman is the cause of the denial of insurance coverage. By substituting prior medical history as the predictive variable relied on by insurers, this harm is cured. All potential insureds with three visits to the emergency room in the past year for treatment of broken bones or surface cuts will be denied coverage-the bar brawler as well as the domestic abuse victim. If one believes instead that the wrong to be righted is that the abuse victim is charged more for coverage or denied coverage because she suffers an unjustly high likelihood of future assault, merely prohibiting the use of the abuse victim category will be unsatisfactory. Alhough both the abuse victim and the bar brawler have a higher than average likelihood of being attacked in future, the bar brawler may justifiably be denied insurance while the abuse victim may not.

The stronger legislation prohibits charging more or denying coverage to potential insureds because of the likelihood they will be attacked again by their abusers. The insurer, when unregulated, attempts to predict the likelihood that the insured will draw from the insurance pool as a result of abuse-related injuries. Call this the insurer's target. Left to its own devices, the insurer uses the insured's status as an abuse victim as the predictor of this target. Alone, the CP forbids only the use of one predictor (abuse victim status), leaving the insurer free to substitute another. The stronger bills forbid the insurer to aim at the target itself.

A good example of such target-based legislation is the federal bill introduced by Representative Ron Wyden (D-Or.) to the House of Representatives in March of 1995. This bill provides:

No insurer may engage in a practice that has the effect of denying, canceling, or not renewing health insurance coverage

${ }^{133}$ S.B. 197, 19th Leg., 2d Sess. (Alaska 1995) (no longer pending); S.B. 1425, 89th Leg., Regular Sess. (Ill. 1995) (awaiting governor's signature as of May 30, 1996); S.B. 1369, 1995 Leg., 1st Sess. (La. 1995); H.B. 5534, 88th Leg., 1st Sess. (Mich. 1995) (health care corporations); H.B. 5533, 88th Leg., 1st Sess. (Mich. 1995) (life and disability insurers); H.B. 5532, 88th Leg., 1st Sess. (Mich. 1995) (HMOs); H.B. 331, 52d Leg., Regular Sess. (Utah 1996); S.B. 138, 92d Leg., 1st Sess. (Wis. 1995); H.B. 43, 53d Leg., Budg. Sess. (Wyo. 1996) (failed introduction).

${ }^{134}$ H.R. 1920, 104th Cong. (1995). In addition, two comprehensive federal women's health bills have been introduced: Women's Health Equity Act of 1996, H.R. 3178, 104th Cong. (1996) and its identical Senate counterpart, S. 1799, 104th Cong. (1996), both of which contain subtitles dealing with insuring domestic abuse victims. Subtitle F, Insurance Protection for Victims of Domestic Violence Act is identical to H.R. 1201, 104th Cong. (1995) and Subtitle G, Domestic Violence Victims Insurance Protection Act of 1996, is identical to H.R. 1920, 104th Cong. (1995). 
or health benefits, or establishing, increasing, or varying the premium charged for the coverage or benefits or excluding health coverage with respect to health care items or services related to treatment of a condition-

(1) to an individual on the basis that the individual or family member is, has been, or may be the subject of abuse, has had prior injuries that resulted from abuse, or seeks, has sought, or should have sought medical or psychological treatment for protection against abuse, or shelter from abuse; . . . . ${ }^{135}$

Prohibiting practices that adversely affect abuse victims will prevent insurers from using all classifications, including prior claims history, to predict future risk of domestic assault. Other strong bills use similar language to achieve the same result. Four of the sixteen enacted state statutes are target laws. ${ }^{136}$ In addition, four proposed federal bills and two proposed state bills are similarly strong. ${ }^{137}$

Just as abuse leaves tracks, such as history of emergency room visits, it also leaves marks. Sometimes the injuries sustained by the abuse victim require ongoing medical care. The abuse victim may be denied coverage for a condition such as a ruptured spleen that resulted from abuse either through a preexisting condition clause or an exclusionary waiver.

The strongest of the bills forbid application of preexisting condition clauses to abuse-related injuries. For example, S.B. 524, introduced by Senator Paul Wellstone (D-Minn.) in March 1995, and its identical House of Representatives counterpart, H.R. 1191, introduced by Representative Charles Schumer (D-N.Y.) also in March 1995, specifically provide that

${ }^{135}$ H.R. 1201, 104th Cong. (1995) (emphasis added). Subtitle F of the Women's Health Equity Act of 1996 is identical to H. R. 3590. See infra note 141.

${ }^{136}$ S.B. 128, 138th Leg., 1st Sess. (Del. 1995) (prohibiting underwriting and rating on the basis of "an individual's history of, status as, or potential to be subject to abuse"); H.B. 4926, 179th Leg., 1st Sess. (Mass. 1995) (prohibiting "not only those [practices] overtly discriminatory but also practices and devices which are fair in form but discriminatory in practice"); H.B. 1100, 180th Leg., 1st Sess. (Pa. 1995) (prohibiting "any . . . underwriting standard or practice which adversely takes into account a history of abuse"); H.B. 2925, 99th Leg., 2d Sess. (Tenn. 1996) (prohibiting adverse treatment on the basis of "an abuse-related medical condition" that has "the purpose or effect of treating abuse status as a medical condition or underwriting criterion").

${ }^{137}$ S. 467, 105th Cong. (1997) (modifying S. 1630, 104th Cong. (1996)) (prohibits insurer from "directly or indirectly" engaging in any of the practices detailed in the act); H.R. 1117, 105th Cong. (1997) (identical to H.R. 2654, 104th Cong. (1995)) (prohibits insurer from "directly or indirectly" engaging in any of the practices detailed in the act); H.R. 3145, 104th Cong. (1996) (prohibiting insurer from denying, canceling or varying terms of coverage because of abuse status or because insured "has had prior injuries that resulted from an act of domestic violence"); H.R. 1201, 104th Cong. (1995); H.B. 4316, 1996 Leg., Regular Sess. (W. Va. 1996) (forbidding surcharges or limits of coverage because of "an individual's history of, status as or potential to be subject to abuse"); H.B. 1457, 143d Leg., Regular Sess. (Ga. 1995) (prohibits insurer from "directly or indirectly" engaging in any of the practices detailed in the act). 
"a health benefit plan may not consider a condition or injury that occurred as a result of domestic violence as a preexisting condition." 138 If an insured makes a claim for treatment to a damaged spleen that was damaged from abuse prior to purchase of the policy, this spleen damage may not be considered a pre-existing condition. Even if the policy has a preexisting condition clause, the insurer may not deny coverage in this case. The bills leave the insurer free, however, to draft insurance policies that exclude coverage for conditions caused by abuse if the conditions are known at the date of policy purchase.

These two bills are unique in their treatment of abuse-related preexisting conditions. Moreover, none of the legislation protects the abuse victim from being denied coverage for ongoing abuse-related medical problems explicitly excluded by the policy at the date of purchase, known as exclusionary waivers. The rest of the legislation is either silent on these issues or, more commonly, expressly permits insurers to underwrite and risk rate on the basis of conditions caused by abuse so long as the condition is one for which the insurer underwrites or risk rates generally. For example, the Maryland law includes the following limitation: "This section may not be interpreted to preclude an insurer from using mental or physical conditions, regardless of cause, in determining the eligibility, rate, or underwriting classification of the applicant or insured." 139 Thus, if a woman has been beaten by her partner, leaving her with a damaged spleen that will require continuing medical care, an insurer in Maryland can either write the policy expressly limiting coverage for related problems or deny coverage for a period of time based on the fact that since the beating occurred prior to the policy period, the injury is a preexisting condition.

The fact that most of the legislation affords no protection to abuse victims with ongoing medical problems caused by abuse demonstrates the dominance of the status conception of the wrong. It is wrong, according to this conception, to base underwriting or rating decisions on abuse victim status. However, if one is denied coverage because of a damaged spleen, and others with damaged spleens are similarly treated, there is no injustice. The status conception misconceives the problem. If the abuse victim is entitled to spread the cost of the increased risk she faces because we suspect she has been unfairly underprotected, then what matters is that she has higher costs which result from abuse, not how one identifies that fact.

${ }^{138}$ The Victims of Abuse Access to Health Insurance Act, S. 524, 104th Cong. (1996). This bill type offers the strongest protection for abuse victims in the health insurance market, though other bills offer more security to abuse victims by extending protection to other forms of insurance.

${ }^{139}$ H.B. 39, 1996 Leg., Regular Sess. (Md. 1996) (emphasis added). 
The last type of legislation in the recent crop of proposed and enacted statutes passes authority to draft rules and regulations to another person or body. For example, the bill currently pending in New Mexico instructs "the department of insurance of the state ... to investigate and report on the lack of health or life insurance coverage for victims of domestic violence." ${ }^{140}$ Representative Earl Pomeroy's (D-N.D.) proposed H.R. 3590 is similar, giving the National Association of Insurance Commissioners (NAIC) ninety days to adopt a model act and regulations to enforce it. ${ }^{141}$

As the above discussion makes plain, the federal bills are generally stronger than the proposed and enacted state legislation. In addition, a federal approach will be more powerful than state-by-state solutions precisely because it is national. Abuse victims in all fifty states will be protected. If justice requires that the higher-than-average insurance costs of the abuse victim be shared, justice requires it for the abuse victims of all states and not simply those whose legislatures have enacted remedial legislation. Second, state laws will be unable to affect the health insurance provided by self-insuring employers. The federal Employee Retirement Income Security Act (ERISA), ${ }^{142}$ which regulates employer-provided pensions and other benefit programs, preempts state regulation of employerprovided benefits. However, ERISA is silent regarding employer-provided health insurance. Thus, although other insurers must comply with the insurance laws of the various states, ${ }^{143}$ self-insuring employers are exempt from these limitations and ERISA provides no others. Since over forty percent of all health insurance is provided by self-insuring employers, this is a significant gap..$^{144}$

The state and federal legislation contains a range of provisions and restrictions. The weakest bills prohibit irrational discrimination only. Those statutes that are slightly stronger forbid the use of the abuse victim classification in all situations. However, since they permit, often explicitly, the use of other methods of predicting which insurance consumers are likely to incur medical costs as a result of future abuse, they are of limited value. The stronger bills also restrict the insurer's ability to aim,

${ }^{140}$ H.J.M. 25, 42d Leg., 2d Sess. (N.M. 1996). Legislation passed in May of 1995 in lowa contains a similar buck-passing provision. See 1995 IowA ACTs 180 § 18.

${ }^{141}$ H.R. 3590, 104th Cong. (1996).

14229 U.S.C. $\$ \S 1001-1461$ (1994).

${ }^{143}$ Each state has adopted an Unfair Trade Practices Act, modeled after the Model Unfair Trade Practices Act drafted by the National Association of Insurance Commissioners (NAIC) shortly after the McCarran-Ferguson Act, ch. 20, 59 Stat. 33 (1945) (codified as amended at 15 U.S.C. $\S \S 1011-1015$ (1994)), was passed in 1945. The Model Act has been amended several times, and separate regulations related to specific unfair trade practices have also been drafted by the NAIC over the years. See 3 BerTram HarnetT \& IRving I. Lesnick, The LaW of Life AND Health Insurance § 12.01 (1991).

${ }^{144}$ See Laura J. Schacht, The Health Care Crisis: Improving Access for Employees Covered by Self-Insured Health Plans under ERISA and the Americans with Disabilities Act, 45 WASH. U. J. URB. \& CONTEMP. L. 303, 311 (1994). 
through means other than the $\mathrm{CP}$, at the target of predicting who is likely to need medical care resulting from future domestic abuse. Finally, the strongest bills go even further, forbidding the treatment of abuse-related injuries as preexisting conditions.

The weak bills are misguided. Legislation protecting the abuse victim's access to insurance at prices equal to prices charged otherwise similarly situated insureds is necessary because the abuse victim, unlike others who are substandard risks, faces risks due to society's failure to protect her adequately. This rationale for insurance protection supports extending coverage in all cases where adverse insurance treatment results from domestic violence regardless of how it is identified by the insurer. Therefore the abuse victim is entitled to insurance protection for denials grounded on poor medical history where this results from abuse, as well as denials or exclusions from coverage for preexisting medical conditions where these are caused by abuse. There is no principled reason to support the $\mathrm{CP}$ and not the broader restrictions. Forbidding the abuse victim category will hamper the insurer's ability to underwrite and rate insureds on the basis of factors created by abuse. As such, this prohibition will constitute an improvement over no action. However, the effect will be largely palliative. The argument of Part I supports treating abuse victims differently from other insureds. Contrary to what some supporters of the legislation maintain, abuse-related injuries ought to be singled out and their costs specifically shared with others in the insurance community.

\section{Conclusion}

The states that have enacted legislation restricting insurer use of the abuse victim classification have adopted the right policy. This legislation, especially the stronger laws, does afford the abuse victim special protection-but it is warranted. The state has a clear and uncontroversial obligation to provide crime protection and to do so on a fair basis, an obligation acknowledged by those on the political right and left. The suspicion that an illegitimate tolerance toward domestic violence has affected the amount of protection afforded domestic abuse victims, and consequently, the degree of safety they enjoy, means that the state has likely failed to provide the required crime protection fairly. As a result, the community should share the cost the abuse victim faces by virtue of the fact that she is a poor insurance risk.

The principal argument offered by critics of the legislation, namely that the abuse victim's dangerous lifestyle choice legitimates charging her a rate that refelcts the dangers of that choice, is flawed. First, on its own terms, the argument is only capable of justifying denying coverage to abuse victims who stay with batterers; those who leave have surely exercised choice in favor of safety. Second, the fact that a choice is voluntary 
is not sufficient to hold a person accountable for it. If a person must suffer greatly or give up important aspects of a good life in order to safeguard health, we ought not to hold her accountable for failing to do so. Just as the person who requires constant bedrest to maintain good health is not accountable for the health decline occasioned by ordinary life activity, so a person ought not to be held responsible for failing to renounce a spouse or partner. Giving up an intimate relationship is a significant loss. This argument does not make a special case for the abuse victim. Rather, it claims that giving up a partner is a great burden for anyone, and as such, no one, the abuse victim included, ought to be accountable for the poor health that results from the failure to do so.

This argument about accountabiltiy for health answers the claim that the abuse victim, more than the cancer sufferer, is legitimately charged an actuarially accurate rate. But the abuse victim is not more accountable for her poor health status than the cancer sufferer, neither is she less so. The reason we treat her differently, mandating the sharing of her health costs, but not those of the cancer victim, is that society is partly to blame for her high-risk status. She is too risky to insure at the average rate because she is more likely than the average insured to be attacked. If this fact, documented by the insurer itself, results from an illegitimate tolerance of domestic violence, then society must share in the costs and burdens the abuse victim bears as a result. The legislation discussed represents one method for the community to comply with this obligation. 
HeinOnline -- 32 Harv. C.R.-C.L. L. Rev. 4121997 